\title{
Hypothyroidism: Diagnosis and Screening,
}

\section{Genetic Influences, and Treatment Options}

\section{Paola Torres-Manzo ${ }^{1}$, Edgar Cano-Europa ${ }^{2}$, Vanessa Blas-Valdivia ${ }^{1}$, Margarita Franco-Colin ${ }^{2}$ and Rocio Ortiz-Butron ${ }^{1}$ *}

${ }^{1}$ Laboratorio de Neurobiología. Departamento de Fisiología "Mauricio Russek Berman" and

${ }^{2}$ Laboratorio de Metabolismo I. Departamento de Fisiología

Escuela Nacional de Ciencias Biológicas, I.P.N. Av. Wilfrido Massieu s/n

Esq. Manuel L. Stampa, Col. Unidad Profesional Adolfo López Mateos

Del. Gustavo A. Madero, C.P. 07738

*Corresponding author: Rocio Ortiz-Butron, Ph.D

Escuela Nacional de Ciencias Biológicas

Av. Wilfrido Massieu s/n, Esq. Manuel L. Stampa

Col. Unidad Profesional Adolfo López Mateos

Del. Gustavo A. Madero, C.P. 07738

México D.F.

Telephone: (525) 729-6300/62348, 52342

Copyright (C) 2014 Paola Torres-Manzo et al. This is an open access article distributed under the Creative Commons Attribution License, which permits unrestricted use, distribution, and reproduction in any medium, provided the original work is properly cited.

\begin{abstract}
The thyroid hormone 3, 5, 3'-triiodothyronine $\left(\mathrm{T}_{3}\right)$ is a key regulator of the development, differentiation, and physiology of all cells in an organism. One of the most studied effects of the thyroid hormone is its control of the basal metabolic rate. Thus, modifications in thyroid hormone levels can produce several alterations, including modifications to the REDOX environment, alterations to signal transduction on several levels, and finally cell death. The aim of this review is to describe primary, secondary, and tertiary hypothyroidism from embryonic and fetal development through to the adult organism. In addition, we explore thyroid hormone resistance causes hypothyroidism. Furthermore, we describe how genetic
\end{abstract}


studies illustrate that mutations can cause hypothyroidism. We will present results from clinical and laboratory tests, in diagnosing hypothyroidism that have been used by different organizations to study thyroid diseases. In addition, we propose some methods for diagnosing hypothyroidism in communities that lack the medical infrastructure to use modern methods of diagnosis. We will present a series of cases that demonstrate the importance of diagnosing hypothyroidism during pregnancy, and in the first years of life for the healthy development of the nervous and cardiovascular systems, and the kidney, among others. We describe current treatments for hypothyroidism, but we will put special emphasis on evidence-based personalized treatment for individual patients. Finally, we will include a section that discusses the benefits and complications of hypothyroidism as it relates to cytoprotection, cell damage, and immunomodulation.

Keywords: Hypothyroidism, Screening, treatment options, cytoprotection, cell damage, immunomodulation

\section{Introduction}

Our review summarizes, to date, what is known about hypothyroidism from embryonic and fetal development through to the adult organism. This review does not attempt to be exhaustive, but instead we refer the reader to the $\sim 15,000$ papers identified by a PubMed search for pathological conditions related to hypothyroidism. However, we do seek to relay the importance of maintaining an adequate supply of thyroid hormones in the perinatal period for the optimal operation of all systems. Furthermore, we stress that the restoration of thyroid hormones at birth, will not prevent metabolic and/or behavioral alterations in adulthood. To do so, we will begin by describing general thyroid development and function, some types of hypothyroidism, its etiology, and different diagnoses.

Normal fetal thyroid gland development, and fetal and neonatal thyroid function is critical for normal prenatal and postnatal brain and organ development, and metabolic processes. In general, euthyroidism describes normal thyroid function, hypothyroidism refers to low thyroid function, and hyperthyroidism indicates high thyroid function. Traditionally, many researchers of thyroid function have focused on the secretion on thyroid hormones $\left(\mathrm{T}_{3}\right.$ and $\mathrm{T}_{4}$ ) and their relationship with hypothalamic and adenohypophysis regulating hormones (TRH, thyrotrophin-releasing hormone; and TSH, thyrotrophin). However, at present we need to also consider the quantity of thyroid hormone receptors and their ligand affinity. In this chapter, we will describe only hypothyroidism, its causes, diagnosis, screening, and treatment.

The thyroid gland is one of the most interesting glands in the body, because it is the first gland in an embryo to produce hormones that regulate multiple developmental processes. From weeks 4 to 6 , thyroglobulin is synthesized, and between weeks 8 and 10 iodine trapping occurs. These events lead to production of $\mathrm{T}_{3}$ and $\mathrm{T}_{4}$ from week 12. Regulating hormones are synthesized in the fetal stage: thyrotropin-releasing hormone (TRH) is synthesized between weeks 6 and 8, and thyroid-stimulating hormone (TSH) is secreted 12 weeks after birth (103). During embryogenesis, thyroid endoderm progenitor cells different- 
iate into thyroid follicular stem cells in their respective pharyngeal pouches $(3 ; 47)$. The thyroid primordium develops because there are inductive signals between it, the pharyngeal endoderm, and the visceral mesoderm. Using animal models, early thyroid development depends on NKX-2, PAX8, FOXE1, and HHEX to proceed normally. Thyroid gland budding occurs concomitantly with the recruitment of new progenitor cells, and their proliferation is the most important process for bud outgrowth in the thyroid primordium. After that, the developing thyroid gland migrates because epithelial cells acquire the capacity to migrate by distinct signaling pathways that express N-cadherin and FOXE1 (7). Also, it has been proposed that the neural crest in the thyroid gland participates in C-cell origin. The final shape of the thyroid is likely influenced by the growing trachea and esophagus (47).

Sometimes, the development of the thyroid gland in the fetus may be modulated by fetal signaling pathways, as we mentioned above, as well as the mother's thyroid state. These two factors can change the intracellular fetal environment, which could lead to the development of congenital hypothyroidism. However, there are other factors that cause hypothyroidism in children and adults. For example, low iodine availability due to diet deficiencies and environmental pollution, and/or hypothalamic or adenohypophyseal dysfunction due to errors in set points or tumors. Some researches have described other important types of hypothyroidism, such as a resistance to thyroid hormones that may onset prenatally, or mutations that alter their function.

Finally, hypothyroidism can be classified into three types, depending on the type of thyroid axis dysfunction:

1. Primary: Refers to a type of hypothyroidism when the dysfunction of the regulating system occurs in the thyroid gland in the form of a low concentration of TH. This could be because, during gestation, the thyroid gland presents morphogenetic errors that modify the normal components of the thyroid gland as TSH receptors (quantity or/and affinity) and the enzymes involved in TH synthesis as thyroperoxidase (TPO, EC 1.11.1.8) (24). Also, there are environmental factors that can cause primary hypothyroidism, such as the sodium/iodine symporter (NIS) inhibitors, perchlorate, thiocyanate, and nitrate, which pollute the surrounding areas. In addition, there are other chemical compounds, such as the isoflavones, genistein and daidzein, which inhibit TPO, thereby inhibiting thyroid hormone formation. The main dietary sources of isoflavones are soy products, peas, beans, nuts, grain products, coffee, and tea. Finally, hepatic deionidation of $T_{4}$ to $T_{3}$ contributes largely to the plasma concentration of $\mathrm{T}_{3}$ in serum, which actively participates in the $\mathrm{TH}$ regulating system. Organochlorine pesticides, dioxins, and furans, which decrease $\mathrm{T}_{4}$ half-life by activating hepatic enzymes, may also induce hypothyroidism (100).

2. Secondary: This type of hypothyroidism is characterized by low TSH levels from adenohypophyseal dysfunction, caused by tumors (112) or an insensitivity to TRH receptors in thyrotrope cells (61). If there are low levels of TSH, thyroid gland activity is low, and the compensatory mechanism of the regulating system increases its TRH secretion. However, in this case a malfunction in the adenohypophysis results, and the levels of TSH do not change. 
3. Tertiary: This type of hypothyroidism is characterized by low serum concentrations of TRH, due to a tumor in the hypothalamus. In addition, TRH-target cell response may be modulated by the rate of degradation of the hormone at specific target sites. This mechanism could effectively control the intensity of stimulation and/or the duration of TRH action (118).

\section{Congenital hypothyroidism}

\section{Definition}

Congenital hypothyroidism $(\mathrm{CH})$ is defined as a thyroid hormone $(\mathrm{TH})$ deficiency at birth that occurs in 1/3000 newborns. It is one of the most common preventable causes of mental retardation. Most infants with $\mathrm{CH}$ do not show an obvious clinical manifestation of hypothyroidism at birth. This may result from residual neonatal thyroid function, because of an over expression of desionidase (EC 1.97.1.11) by compensatory mechanisms in target organs, or in the TH received from breast milk (103).

Congenital hypothyroidism is classified as either permanent or transient. Permanent $\mathrm{CH}$ is a persistent deficiency of thyroid hormone that requires lifelong treatment. Transient $\mathrm{CH}$ refers to a temporary deficiency of thyroid hormone. In this case, diagnosis at birth is the essential first step towards individuals receiving treatment and recovering to a euthyroid state. Recovery to euthyroidism typically occurs in the first few months or years of life. Permanent $\mathrm{CH}$ can be further classified into permanent primary, where the thyroid gland is directly affected, or secondary, where the central nervous system is affected.

\section{Etiology}

Thyroid hormone deficiency at birth is most commonly caused by a problem in thyroid gland development (dysgenesis). Recently, mutations in the NKX2 and PAX8 genes (64-66; 85) have been reported to be associated with thyroid dysgenesis, or a disorder of thyroid hormone biosynthesis (dyshormonogenesis). This relationship with resistance to thyrotropin (TSH) action is the disease associated with molecular defects that hamper the adequate transmission of signals. The defect may, in principle, affect every step along the cascade of events following the binding of TSH to its receptor (TSHR) on thyroid cell membranes. TSH resistance is a disease with a broad range of expressivity, ranging from severe congenital hypothyroidism $(\mathrm{CH})$ with thyroid hypoplasia, to mild hyperthyrotropinemia (hyperTSH) associated with an apparent euthyroid state (101). Basolateral iodide transport defects may be caused by mutations in the SLC5A5 (sodium iodide symporter) gene, a defect in apical iodide efflux caused by mutations in the SLC26A4 (PDS) gene, mutations in the thyroglobulin gene, defects in iodination and coupling of thyrosyl moieties due to mutations in the thyroid peroxidase gene, defects in hydrogen peroxide generation caused by mutations in the DUOX2 or DUOXA2 genes, or defects in the recycling of intrathyroidal iodine due to mutations in the iodotyrosine deiodinase (also known as DEHAL) (57).

In addition, 12 different NIS molecular defects have been linked to an iodide transporter defect (ITD) in 31 ITD patients that developed hypothyroidism. Interestingly, marked clinical heterogeneity between patients with the same NIS mutation and those with different 
mutations in the NIS gene, in the absence of a clear genotype-phenotype correlation, has been observed. The study of NIS mutations as the molecular basis of ITD has not only yielded extremely valuable structural/functional information on NIS, but has also provided an important tool for preclinical diagnosis and genetic counseling of ITD patients (124).

\section{Congenital hypothyroidism disease screening}

An early diagnosis of hypothyroidism using either primary thyroxine (T4)-follow-up thyroid stimulating hormone (TSH), or primary TSH testing as a diagnostic test, is essential to the prognosis. Many programs in the US and around the world continue to prefer a primary T4follow-up TSH testing strategy (102). Interestingly, the American Association of Clinical Endocrinologists (AACE) recommends routine screening for all pregnant women, but the United States Preventive Services Task Force (USPSTF) and the American Congress of Obstetricians and Gynecologists (ACOG) have not endorsed routine screening (74).

Another test that measures trimester-specific reference ranges for thyroid-stimulating hormone (TSH) and free thyroxine in pregnancy, takes into account iodine and thyroid autoantibody status, race, and BMI, as well as other factors. This type of testing is suggested only for pregnant women at an increased risk for thyroid disease, but in fact, misses $30-80 \%$ of women with thyroid disease (91).

Neurodevelopmental outcome is directly related to early diagnosis and treatment. Infants detected through newborn screening programs, and started on $\mathrm{T}_{4}$ in the first few weeks of life, have a normal or near-normal neurodevelopmental outcome. Figure 1, depicts the screening process for congenital hypothyroidism. The recommended $\mathrm{T}_{4}$ starting dose of 10 $15 \mu \mathrm{g} / \mathrm{kg} / \mathrm{d}$ is higher on a weight basis than is the dose for children and adults. Tailoring the starting L-T4 dose to the severity of the hypothyroidism will normalize serum T4 and TSH as rapidly as possible (79). Congenital hypothyroidism, due to thyroid dyshormonogenesis, is a heterogenic disorder that may be caused by mutations in any of the known steps in the thyroid hormone biosynthesis pathway. An exact molecular diagnosis allows for genetic counseling, and the identification of asymptomatic mutation carriers at risk of recurrent hypothyroidism, meanwhile providing a rationale for adjunct iodide supplementation (57).

\section{Subclinical hypothyroidism}

Because thyroid hormones play an important role in many physiological processes, such as differentiation, growth, development, and the physiology of all cells, their modification can produce several alterations on various levels. Thus, their deficiency or excess may lead to an extensive array of clinical manifestations, including neurological and psychiatric symptoms (17). However, many people display subtle symptoms, although their serum free T4 and T3 levels are within their respective reference ranges. These patients may express one or more symptoms, such as migraines, hair loss, hypertension, excessive weight gain, peeling skin, infertility, pregnancy complications, and/or a predisposition to infections, among others. In these cases a diagnosis of subclinical thyroid disease, mild thyroid failure, or subclinical hypothyroidism is given. Other possible symptoms include those related to cognitive functions, such as memory deficit, despondency, as well as symptoms of depression and anxiety (2). 


\section{Definition}

Subclinical thyroid disease is a condition of mild to moderate thyroid failure, characterized by normal serum levels of thyroid hormones, with a serum TSH level above the upper limit of normal (supranormal) $(2 ; 19 ; 37)$. Due to the wide range of mild symptoms, multiple investigations over the past 20 to 30 years have been done in an attempt to classify it. Based on serum TSH levels, some investigators have divided subclinical thyroid disease into 3 grades (Table 1) (146), while others have divided it into two categories: individuals with mildly increased serum TSH levels $(4.5-10 \mathrm{mUI} / \mathrm{L})$, and those with more severely increased serum TSH levels (>10 mUI/L) (126).

It is very important to mention that the term "subclinical" may not be strictly correct, since some of these patients may have clinical symptoms, however, to date a more appropriate name has yet to be proposed. In some cases, patients with normal or minimally deviant serum T3 concentrations, present a hypoplastic or normally sized gland properly positioned in the neck. Depending on the degree of impairment of TSH receptor (TSHr) function, patients display a variety of symptoms in addition to those previously mentioned (i.e. memory deficit, despondency, symptoms of depression and anxiety) (2).

\section{Etiology}

The etiology of subclinical hypothyroidism is extremely broad due to variety of factors that can induce it. One cause may be via chronic lymphocytic thyroiditis, an autoimmune disorder of the thyroid gland $(9 ; 126)$. Alternatively, it may occur following a subacute, postpartum, painless thyroiditis, or after a partial thyroidectomy $(19 ; 37)$ Shibayama and colleagues used neonatal screening to identify a mutation in the thyrotropin receptor (TSHR) gene in a patient with subclinical hypothyroidism. In their study, they found a mild dysfunction of the R450H mutant on the TSHR gene, and it correlated it with mild clinical and biochemical manifestations (121).

Some drugs can inhibit thyroid hormone production, for example, lithium carbonate (19; 37), cytokines, and interferon (30). Amiodarone, a benzofuranic-derivative, iodine-rich drug used to treat tachyarrhythmia can induce subclinical hypothyroidism (12).

Other thyroid damaging factors that have been related to this disease include, exposure to various pesticides, herbicides, industrial chemicals, and environmental chemicals (54).

It is important to remember that a thyroid hormone deficiency, before and during pregnancy, induces a transitory subclinical hypothyroidism state that can result in high maternal and fetal disease risk $(19 ; 37)$. In fact, risks can be as serious as perinatal mortality, increased fetal distress, preterm birth, and impaired mental and somatic development $(56 ; 78)$.

\section{Subclinical disease screening}

Initially a diagnosis would be based on symptoms, however, as previously mentioned, symptoms can be minimal and are sometimes not the motivation for a hospital visit. To more accurately diagnosis subclinical hypothyroidism, TSH levels should be measured and an estimate of T4 values should be made, in addition to the evaluation of symptoms related 
to hypothyroidism. However, both TSH and T4 display large variations between individuals, and can occasionally exceed the outer limits of reference ranges $(19 ; 49 ; 78 ; 127 ; 146)$. Moreover, in many cases, patients with subclinical hypothyroidism have only marginally high TSH levels and T4 values that may be low but fall within the normal range of reference (Figure 2). Hence, serum TSH measurement is necessary for the diagnosis of mild thyroid failure, particularly when peripheral thyroid hormone levels are within the normal laboratory range (37). Since reports show that serum TSH has a log-linear relationship with circulating thyroid hormone levels (a 2-fold change in free thyroxine will produce a 100-fold change in TSH) (49), it is important that we determine the upper limit serum TSH value. Evidence shows that the presence of antithyroid antibodies can be detected in patients with a serum TSH level between 3 and $5 \mathrm{mIU} / \mathrm{L}$, and a progressively higher rate towards clinical thyroid disease $(83 ; 144)$. This suggests that $3 \mathrm{mIU} / \mathrm{L}$ may be the upper limit of serum TSH (49). Fatourechi has found that patients with a TSH level between 3.0 and $5.0 \mathrm{mIU} / \mathrm{L}$ are more likely to have positive antithyroid antibodies (22), and future thyroid disease. However, there is a lack of evidence for a beneficial outcome using levothyroxine therapy at these levels, indicating that an upper limit of TSH between 4.0 and $5.0 \mathrm{mIU} / \mathrm{L}$ (depending on the laboratory) may be more appropriate (49). Some investigators have mentioned that it may be difficult to distinguish between the transient disturbance of thyroid gland function and mild thyroid failure (Table 2) $(19 ; 37)$. Since this condition could be temporary, a follow-up test should be performed to reevaluate the TSH concentration after 6 to 12 months.

The diagnosis of autoimmune thyroid disease remains unclear with the currently available in vitro and in vivo tests. Recently, Calebiro and coworkers demonstrated that TSHr mutations are retained in the endoplasmic reticulum, probably as a consequence of protein mis-folding, but maintain the capability to associate with wtTSHr. For this reason, wtTSHr is entrapped intracellularly, providing a molecular basis for the dominant form of partial TSH resistance associated with a heterozygous mutation in the TSHr gene (27). Similarly, in mice TTF-1 haploinsufficiency produces hypothyroidism mainly through reduction in TSHr gene expression, which is partially compensated for by an increase in serum TSH (92).

\section{Should subclinical hypothyroidism be treated?}

We know that subclinical thyroid dysfunction is a risk factor for developing symptomatic thyroid disease. Probably, early treatment can prevent serious morbidity in individuals who are found to have laboratory evidence of subclinical thyroid dysfunction.

In 1998, the American College of Physicians recommended treatment on an individual basis (or repeating serum TSH yearly) for patients with a TSH level between 5 and $10 \mathrm{mIU} / \mathrm{L}$. Treatment should be considered if the patient has positive thyroid peroxidase antibodies, is symptomatic, or has high cholesterol; otherwise, yearly monitoring is advised (62). Later, in 2004, a consensus conference panel on subclinical thyroid announced that they do not recommend routine treatment for patients with TSH levels between 4.5 and $10 \mathrm{mIU} / \mathrm{L}$, but that thyroid function tests should be repeated at 6- to 12-month intervals, to monitor for changes in TSH levels. For TSH levels above $10 \mathrm{mIU} / \mathrm{L}$, the evidence remains too inconclusive to recommend with certainty for or against treatment $(5 ; 6 ; 126)$. 
Since 2004, Helfand has been of the opinion that in the general population, an undetectable TSH level is a risk factor for the later development of overt hypothyroidism (62). Evidence shows that L-thyroxine reduces symptoms (but not lipid levels) in patients who have a markedly elevated TSH level $(10 \mathrm{mIU} / \mathrm{L})$, following surgery or radioiodine treatment. However, in apparently healthy patients who have mildly elevated TSH levels (4 to 7 $\mathrm{mU} / \mathrm{L}$ ), the largest group identified by screening, the frequency of hyperlipidemia and related symptoms may be no different from that of euthyroid individuals $(36 ; 90 ; 125 ; 133)$.

It is well known that most infants with overt hypothyroidism that are promptly diagnosed and treated proceed with normal growth and development. This is because a standardized protocol, using thyroid ultrasonography, is a safe and sensitive approach to a trial off of thyroxine in select patients (46). Perhaps, in many countries, there are no guidelines on the management of infants diagnosed with subclinical or mild hypothyroidism, and therefore likely no further follow-up is performed. This may explain why infants with subclinical, mild, or even transient hypothyroidism, are associated with adverse future neurodevelopmental consequences, as well as genetic and morphologic abnormalities. For this reason, it is highly recommended that follow-up be performed $(25 ; 38)$.

Perhaps subclinical hypothyroidism is as common as occurring in 3-8\% of the US population, however, because many cases of thyroid disease remain undiagnosed (49), a true value is difficult to establish. In this chapter, attention has been drawn to the potentially high risk of the disease; however, symptoms may be subtle and can be related with another manifestations, such as child failures in courses like math or chemistry, or even with symptoms of depression and anxiety. How can this be? Probably because a mutated thyrotropin receptor caused by protein mis-folding or other stimuli (i.e. genetics, industrial chemicals, and environmental chemicals), is retained in the endoplasmic reticulum causing modifications on the central level. This is known as the paraventricular nucleus, a hypothalamic area containing the $\mathrm{T}_{3}$ axis set point (35). Catecholamines are believed to increase the set point for inhibition of TRH gene expression by T3, thereby permitting high circulating levels of $\mathrm{TH}$ to contribute to the increased thermogenesis necessary to remain alert. Catecholamines act on TRH neurons primarily through $\alpha 1$ adrenergic receptors (8) that can induce the phosphorylation of the cAMP response element binding protein (CREB) (131). CREB activates the TRH promoter by binding to a CREB response element in the promoter, which overlaps with a TR binding site (94). It is known that adrenergic fibers in contact with TRH neurons produce cocaine and amphetamine neuropeptides and neuropeptide Y (NPY) $(149 ; 150)$. Cocaine and amphetamines are related with the transcript (CART) that exerts a stimulatory effect on the synthesis and release of TRH (50). In contrast, NPY exerts a potent inhibitory effect on the transcription of the TRH gene (51), through inhibition of the cAMP-CREB second messenger pathway (113). Thus, it is suggested that alterations to these pathways alter the TRH set point, and consequently modifies TSH levels. 


\section{Syndromes of reduced sensitivity to thyroid hormone}

\section{Thyroid hormone resistance syndrome (RTH)}

Thyroid hormone (TH) is important for the development and maintenance of almost all tissues $(110 ; 152)$. The majority of its actions are mediated by nuclear receptors called $\mathrm{TH}$ receptors TR $\alpha$ and TR $\beta$, which are encoded by two separated genes located in human chromosomes 17 and 3, respectively (34). In 1967, Refetoff and coworkers discovered a rare syndrome in an individual that combined deaf-mutism, stippled epiphyses, and goiter, which they called refractoriness to thyroid hormone or Refetoff syndrome (105).

Today, that disease is called thyroid hormone resistance syndrome, and it is the most commonly occurring related disease for a set of genetically autosomal dominant defects that can interfere in the biological action of a chemically intact, normally secreting thyroid (43). This syndrome is characterized primarily by elevated amounts of circulating thyroid hormones with nonsuppressed thyrotropin (TSH) levels, reflecting resistance within the hypothalamic-pituitary-thyroid axis, but with variable refractoriness to hormone actions in peripheral tissues (108). Since it is not detected by routine neonatal screening for hypothyroidism, RTH incidence is calculated as occurring in $1 / 40000$ live births $(79 ; 129)$.

According to the signs and symptoms of the patients, RTH was divided initially into two different categories called central resistance to thyroid hormones (CRTH), which characterized patients with resistance to $\mathrm{TH}$ at the hypothalamus and hypofisis levels; and generalized resistance to thyroid hormones (GRTH), where peripheral resistance to thyroid hormone actions is observed. However, this classification is no longer used in clinics since identical mutations were found in nonrelated individuals, who were initially diagnosed as either GRTH or CRTH patients, and because of an absence of distinct laboratory differences (14). For these reasons, many authors consider GRTH and CRTH as part of the same genetic spectrum of disorders $(1 ; 14 ; 15)$.

The main causes of RTH, and the syndromes of low responsiveness to thyroid hormone, include mutations in the genes THRB, THRA, SLC16A2, and SECISBP2 (or SBP2), which encode for thyroid hormone receptors $a$ and $b$, the monocarboxylate transporter 8 , and for several selenoproteins, respectively.

\section{Mutations in THR $\beta$ and THR $\alpha$}

TR $\alpha$ and TR $\beta$ are members of a family of nuclear receptors. They have structural and sequence similarities in their DNA, and their ligand domains differ mostly in their amino terminus (69). Alternative splicing and promoter usage produce two major TR $\alpha$ (TR $\alpha 1$ and $\operatorname{TR} \alpha 2)$ and $\operatorname{TR} \beta$ (TR $\beta 1$ and TR $\beta 2$ ) isoforms (13). The most important are the three isoforms that can bind to $\mathrm{T}_{3}(\mathrm{TR} \alpha 1, \mathrm{TR} \beta 1$ and $\mathrm{TR} \beta 2)(84)$, and regulate its target genes via recruitment of coregulatory complexes $(33 ; 68)$.

Approximately $85 \%$ of individuals with RTH have mutations in their THRB gene. These mutations are located in the "hot spots" or CG isles (dinucleotide CG-rich zones). As of December 2012, at least 128 mutations had been identified in THRB, among which 111 
were missense/nonsense mutations, 6 small deletions, 6 small insertions, 2 small indel, 2 gross deletions, and 1 regulatory mutation (104).

Most of the mutations in the HTRB gene are autosomal dominant, and only the original case described by Refetoff and colleagues in 1967, had a recessive inheritance due to a complete deletion of the gene (105).

RTH caused by defects in TR $\beta$ (or classic RTH) are characterized by elevated levels of serum free $T_{3}$ and $T_{4}$ in the presence of normal or slightly elevated TSH (147). Clinically, patients can present goiter (95\% of the cases), tachycardia, osteoporosis, short stature, delayed dentition initiation, deafness, and retarded bone age. In the central nervous system, some alterations are evident in learning disabilities, language impairment, mental deficiency with low IQ (5-10\% of the cases), and attention deficit hyperactivity disorder (ADHD) (18). Metabolic changes include hyperphagia and increased energy expenditure.

Mutations in HTRA were not discovered until the year 2012, when a nonsense mutation that produced a truncated TR $\alpha$ lacking its C-terminal $\alpha$-helix, was identified in a 6 year-old girl with growth and developmental delay (21). A different mutation was found in another individual (137), but both reported low serum $\mathrm{T}_{4}$, high serum $\mathrm{T}_{3}$, and very low $\mathrm{rT}_{3}$.

\section{Screening and diagnoses}

Clinicians predominantly suspect the presence of RTH in patients who have elevated serum concentrations of $\mathrm{T}_{4}, \mathrm{~T}_{3}$, and $\mathrm{rT}_{3}$ with normal or elevated $\mathrm{TSH}$, especially when goiter is present. However, RTH can be confused with Grave's disease, which is consistent with the presence of goiter, as well as other disorders, such as tachycardia and hyperactivity. For this reason, detecting the basal concentration of TSH (which is nonsuppressed in RTH), and the presence of circulating antibodies against TSH-receptors (present in Grave's disease) may help to make a correct diagnosis. Nevertheless, there are cases where both pathologies are present in the same patient (122).

TSH-secreting pituitary adenomas are pathologies that may also be confused with RTH, since an increase in serum TSH is also present, especially in the $\alpha$ subunit. The diagnosis of an adenoma is established by radiologic exploration and a ratio of a-subunit:TSH $(>1)$.

Some disturbances to transporters can also be wrongly diagnosed. RTH, for example, will show increased total serum $\mathrm{T}_{4}$ and normal TSH levels, especially in familiar dysalbuminemic hyperthyroxynemia, where there is a circulate albumin with a high affinity for $\mathrm{T}_{4}$; normally only $10 \%$ of $\mathrm{T}_{4}$ is bound to albumin, but in this case $30 \%$ of $\mathrm{T}_{4}$ is bound to albumin. This elevates total $\mathrm{T}_{4}$ but keeps free- $\mathrm{T}_{4}$ at normal levels (135). Abnormalities with transthyretin have also been diagnosed as RTH or even hyperthyroidism (107).

A specific test for RTH is the $\mathrm{T}_{3}$ suppression test, which consists of administering an increasing dose of $\mathrm{T}_{3}(50,100$ and $200 \mathrm{mg}$ /day) to a patient for 3 weeks (one week per dose). Prior to treatment, and at the start and end of each week, serum TSH is measured. In normal subjects, a dose of $50 \mathrm{mg}$ of $\mathrm{T}_{3}$ can diminish serum TSH concentration, while individuals with RTH need doses higher than $200 \mathrm{mg}$ to achieve the same results (106) 
(Figure 3). The final diagnosis can be confirmed by sequencing TR $\beta$ (only for classical RTH).

\section{NonTR-RTH}

The term nonTR-RTH, refers to a subgroup of individuals that present the characteristic manifestations of RTH, but with no mutations to the TR $\alpha$ or $\operatorname{TR} \beta$ gene. It occurs in approximately $15 \%$ of individuals with $\mathrm{RTH}$, and while classical RTH has no gender discretion, nonTR-RTH is most common in females $(3: 1)(111 ; 148)$.

Even when the genetic defect remains unknown, invitro studies with fibroblast obtained from nonTR-RTH patients reveal resistance to the effect of $\mathrm{TH}$, and an abnormal interaction between the extracts of that fibroblast. Wild-type TR $\beta$ suggest that the defect involves an aberrant cofactor, however, studies of many coactivators, corepressors, and also some cell transporters have found no conclusive results (109).

\section{Treatment of RTH}

RTH treatment is independent of the TR $\beta$ or TR $\alpha$ mutation, and therefore both RTH and nonRT-RTH conditions are treated similarly. Treatment consists of alleviating the symptoms when they exist. Symptoms of TH deficiency are treated with $\mathrm{L}_{-} \mathrm{T}_{4}$, while for excessive TH, $\beta$ adrenergic blockers are used (148).

\section{Thyroid hormone cell membrane transporter defect (THCMTD)}

Previous findings that assured that thyroid hormones $T_{3}$ and $T_{4}$ entered the cells only by passive diffusion (45) were abandoned, when several molecules where identified as cell transporters of thyroid hormones (63). Among these transporters, X-linked Monocarboxylate transporter 8 (MCT8) has been shown to be an important and potent transporter of thyroid hormone into cells (53).

The MCT8 transporter is codified by the SLC16A2 gene, which is located at Xq13.2 on the human chromosome, which has 6 exons and 5 introns (141). This transporter is widely distributed in human liver, kidney, adrenal, ovary, thyroid, and particularly brain tissues, where it is the most important $\mathrm{T}_{3}$ transporter in the neurons; particularly neurons of the cerebral cortex, cerebellum, choroid plexus, and in the capillaries and tanycytes lining the third ventricle (67). MCT8 has also been localized in different nuclei in the human hypothalamus and the pituitary (52). Mutations in the SLC16A2 gene produce a syndrome with both neuropsycomotor and characteristic thyroid test abnormalities, including high $\mathrm{T}_{3}$, low $\mathrm{rT}_{3}$, and slightly reduced concentrations of $\mathrm{T}_{4}$ and $\mathrm{TSH}$. This neurological syndrome is also known as the Allan-Herndon-Dudley syndrome (AHDS), a disease with 100\% penetrance in males (while carrier females may show only mild thyroid test abnormalities) $(42 ; 97 ; 120)$, and is accompanied by truncal hypotonia (in $100 \%$ of cases), limb spasticity, poor head control, dyskinetic movements, and impaired speech. Most AHDS patients are unable to sit, stand, or walk independently, however, there are some cases with a milder phenotype that are able to walk and/or talk, albeit with high difficulty. All individuals with AHDS have mental retardation $(18 ; 42 ; 120)$. 
Around 50 individuals with AHDS have been studied, and many mutations in MCT8 have been identified. These mutations include large deletions, frame-shift mutations, nonsense mutations and deletions, insertions or the substitution of single amino acids that inactivate MCT8 and result in the syndrome described above $(76 ; 141)$. Some of the mutations in MCT8 are listed in Table 1.

\section{Diagnostic}

Total and serum free $T_{4}$ and $T_{3}$ must be measured in individuals with hypotonia. A high level of $\mathrm{T}_{3}$, accompanied by a low concentration of $\mathrm{T}_{4}$, is nearly pathognomonic, but the diagnosis can be confirmed by gene sequencing (18). Other studies include magnetic resonance imaging (MRI), where mild to severe delayed myelination in the brain can be confirmed, and is a common indicator for the disease $(55 ; 138)$. Normally, this disease cannot be diagnosed in the first days of birth, because the typical thyroid test abnormalities of an MCT8 deficiency become apparent only further into the first month after birth.

\section{Treatment}

AHDS patients have low concentrations of serum $\mathrm{T}_{4}$ and modestly increased serum TSH. For this reason, many patients treated with $\mathrm{LT}_{4}$ have experienced no benefit, and may in fact experience detrimental effects. For example, an increased $T_{3}$ exposure to tissues that can perform MCT8-independent $\mathrm{T}_{3}$ uptake, like the heart, may suffer from induced or aggravate tachycardia (75).

Some possibilities for an effective treatment include therapy with a thyromimetic, which is effectively transported into the brain even if the MCT8 transporter is mutated. The $\mathrm{T}_{3}$ analog diiodothyropropionic acid (DITPA) has been clinically tested (40), while preclinical studies are in progress to test the analog 3,5,3',5'-tetraiodothyroacetic acid (Tetrac); in mouse mutants deficient in the MCT8 transporter, has been proven to be metabolized to the TH receptor active compound 3,3',5-Triiodothyroacetic acid (Triac), which is able to replace $T_{3}$ and promote TH-dependent neuronal differentiation in the cerebellum, cerebral cortex, and striatum $(70 ; 139)$.

\section{Thyroid hormone metabolism defect (THMD)}

Selenium is a trace element fundamental for human health. Its biological role is mediated by the cotranslational incorporation of selenocysteine (Sec), a rare amino acid present in the catalytic center of selenoenzymes (41). The function of these proteins are needed for several physiological processes, one of which is the metabolism of thyroid hormones, where deiodinases play a key role in the thyroid hormone activation or inactivation, as well as regulating plasma and intracellular levels of $\mathrm{TH}$. The activation of pro-hormone $\mathrm{T}_{4}$ to hormone $T_{3}$ is catalyzed by type 2 deiodinase (D2) via outer-ring deiodination (87), while type 3 deiodinase (D3) performs inner-ring deiodinations that inactivates both $\mathrm{T}_{4}$ and $\mathrm{T}_{3}$, converting them into $\mathrm{rT}_{3}$ and $\mathrm{T}_{2}$, respectively. Deiodinase 1 (D1) possesses both activating and inactivating activities (86). 
As other selenoproteins, deiodinases are synthetized through a unique mode of translation. Sec is encoded by codon UGA, which in most situations acts as a stop codon. The recoding of a specific UGA is determined by the presence of a selenocysteine insertion sequence (SECIS) in the 3'untranslated region of the protein mRNA. A SECIS-binding protein 2 (SBP2) recognizes the SECIS, recruits multiple factors, and adds Sec to the nascent protein chain (41) (Figure 4).

Alterations in TH metabolism are typically acquired, and often produces "low $\mathrm{T}_{3}$ syndrome" or "nonthyroidal illness" (77). However, in 2005, the first inherited thyroid hormone metabolism defect (caused by a mutation in the SBP2 gene) was discovered in two individuals with growth retardation, who had high total serum and free $\mathrm{T}_{4}$ and $\mathrm{rT}_{3}$ concentrations, low $\mathrm{T}_{3}$, and normal or slightly elevated TSH (44).

The incidence of THMD caused by mutations to the SBP2 gene is still unknown. Nevertheless, as of 2011, mutations were identified in 8 individuals, and it was recognized that their inheritance is autosomal recessive, with equal prevalence in men and women (Table 2) $(10 ; 39 ; 44 ; 60 ; 117)$.

\section{Is a hypothyroid condition good or bad?}

It has previously been mentioned that a deficiency of thyroid hormones results in a decreased metabolism and a lower basal metabolic rate (BMR). However, there is also evidence that supports that hypothyroidism can decrease cellular stress. Tenorio-Velázquez and colleagues have demonstrated that hypothyroidism attenuates oxidative stress and renal injury caused by ischemia-reperfusion, produced by an increase in ROS and reactive nitrogen species (130). It is postulated that the mechanism in affected organs is either a decrease in the general metabolic rate, or a reduced free radical scavenging response after ischemia. In addition, lipid peroxidation in hypothyroid animals with renal ischemia decreased (96), and the content of malondialdehyde reduced, which is an indirect measure of the generation of oxygen free radicals. Alternatively, the cortical content of glutathione, a free radical scavenger, increased. Similarly, in a liver model of hypothyroid-ischemic injury, lipid peroxidation and free-radical generation decreased (128). Hypothyroidism attenuates not only renal, but also cardiac damage caused by ischemia and reperfusion. Bobadilla and coworkers showed that hypothyroidism conferred protection against reperfusion arrhythmias, the cardiac release of creatine kinase and aspartate amino transferase, and preserved the normal structure of the myocardial tissue (20). It has been proposed that hypothyroidism protects against pore opening and heart reperfusion (32). This may be relevant to the protective effect of hypothyroidism in ischemia and reperfusion, because it is recognized that the mitochondria play a key role in cell death pathways, by activating the mitochondrial-permeability transition pore and causing the release of cytochrome $\mathrm{C}$, proapoptotic factors, and the $\mathrm{Ca}^{2+}$ overload that causes a nonselective permeability of the inner membrane. The prolonged opening of the membrane-permeability transition pore during the first few minutes of reperfusion is a critical determinant of cell death, and pharmacological inhibition of the pore at the time of reperfusion protects the cell (58). Previous studies indicate that there is a decrease in glutamate release during hypothyroidism, and that this is correlated to protection in cerebral ischemia (123). The reason why 
hypothyroidism results in a decreased release of glutamate is as yet unknown. It is possible that hypothyroidism affects the release mechanisms in the presynaptic receptors. It is also possible that the hypothyroid state results in an increase in the reuptake mechanism for glutamate.

Perhaps because of the protective effect of hypothyroidism, many clinicians use methimazole to induce this condition. However, there are some indications that antithyroidcaused hypothyroidism can produce cellular damage. Although, some results indicate that it is the chemical structure of methimazole, specifically that induces cellular protection (23; 134). In addition, there is evidence of extrathyroidal effects of antithyroid drugs, such as thionamides, in humans and other animals (11). One of the effects of thionamides is the contribution to oxidative stress and cellular damage. These effects can produce an increase in oxidant species that cause lipid peroxidation, nitration, carbonylation, or glutathionylation of proteins, and fragmentation of DNA $(59 ; 136)$. In light of this research, we determined if methimazole specifically, or hypothyroidism cause cellular damage in several organs. After producing a hypothyroid animal caused by thyroidectomy or methimazole administration, the spleen, heart, liver, lung, and kidney were obtained. A portion of these tissues was processed for histological study, and another portion was used for the biochemical assay to determine oxidative stress. We demonstrated using histological techniques that only methimazole-caused hypothyroidism produces cellular damage in the kidney, lung, liver, heart, and spleen. Animals with methimazole and $\mathrm{T}_{4}$ supplementation showed cellular damage in the lung, spleen, and renal medulla with lesser damage in the liver, renal cortex, and heart. Meanwhile, the thyroidectomy group showed no tissue alterations (28). Moreover, $5 \%$ of patients with hyperthyroidism treated with antithyroid drugs, including methimazole, are reported to have liver $(31 ; 151)$, lung (132) and kidney damage (26). In methimazolecaused hypothyroidism animals, tumorigenic effects (72), and modified pulmonary function (82) have been observed. Similarly, other studies have found no tissue damage in a model of hypothyroidism caused by a thyroidectomy (130). We also compared, over time, markers of oxidative stress, the REDOX environment, and the antioxidant enzymatic system in the liver and the spleen of rats with methimazole- or thyroidectomy-caused hypothyroidism. We found that cellular damage was related to an increase in oxidative stress markers (ROS and lipid peroxidation) that were not compensated for by the antioxidant system. Catalase activity is reduced in hepatic tissue, and this allows for $\mathrm{H}_{2} \mathrm{O}_{2}$-caused hepatic damage (29). The increase of glutathione-cycle enzymes was insufficient to prevent oxidative stress markers (95). All these findings together indicate that methimazole, rather than hypothyroidism is responsible for cellular damage.

Furthermore, evaluation by microscopic analysis of thyroidectomy animals showed no other tissue alterations, with the exception of the lung. There is some evidence that demonstrates molecular mechanisms by which hypothyroidism itself may produce a protected state of the tissues. For example, by reducing the enzyme activity associated with the mitochondrial respiratory chain (99), decreasing the adenine nucleotide translocase (119), reducing activity of cytochrome-C oxidase (98), and resisting formation of permeability transition pore formation of the inner mitochondrial membrane (32). 
With all this evidence, it is important to develop other therapies or antithyroid drugs with fewer side effects. We have suggested that hypothyroidism can be a protective state against toxic agents, and that it is related to an increase in reduced glutathione or $\gamma$-L-glutamylcysteinyl-glycine (GSH) synthesis, and mild immunosuppression.

The mitochondrial concentration of GSH is approximately 11-15 mM. The entry of GSH into the mitochondria depends on electroneutral transporters, such as tricarboxylic or dicarboxylic acids (81). In general, the ratio of GSH/GSSG is greater than 10 for cells and organelles, such as the mitochondria and nucleus, whereas the endoplasmic reticulum has the lowest GSH/GSSG ratio of 1 to 3. The best indicator of the REDOX environment is the $\mathrm{GSH}^{2} / \mathrm{GSSG}$ ratio, because the REDOX environment involves the transfer of electrons, for which the theoretical model of Schafer and Buettner uses the Nernst equation (114). These authors proposed that other REDOX couples could participate in the REDOX environment to maintain the ratios of NADPH/NADP ${ }^{+}$, and reduce thioredoxin/oxidized thioredoxin ( $\mathrm{TrxSH}_{2} / \mathrm{TrxSS}$ ) and $\mathrm{GSH}^{2} / \mathrm{GSSG}$ ratios. These REDOX couples could participate in the maintenance of the REDOX environment, because their $\mathrm{pKs}$ are above the normal physiological $\mathrm{pH}$, and the ratio of the reduced pair to its oxidized counterpart is $1: 100$, 1:1000, or greater. The $\mathrm{GSH}^{2} / \mathrm{GSSG}$ ratio is the most important couple in the REDOX environment, because their chemical structures are not susceptible to any peptidase, and they are used in the cell, particularly for cell antioxidant protection, and not in essential biosynthetic pathways. Also, the $\mathrm{GSH}^{2} / \mathrm{GSSG}$ ratio has the highest concentration of the three REDOX ratios mentioned, and most effectively buffers the REDOX potential changes between -300 and $-100 \mathrm{mV}$, despite varying the concentration of GSH. The change in the half-cell reduction potential of this REDOX couple is related to processes such as cell proliferation, differentiation, apoptosis, and necrosis in biological experiments $(28 ; 59 ; 71$; $73 ; 136)$.

In our group, we are studying the effect of a hypothyroid state and GSH synthesis in various organs, with special interest in the liver and kidney. For these investigations we used thyroidectomyzed rats with a parathyroid gland reimplant (only to affect the thyroid hormone system). Two weeks postsurgery, we determined the GSH content by a fluorometric method, and the $\gamma$-GCS by a spectophotometric method, as described $(29 ; 95)$. In this animal model, we demonstrated that in a hypothyroid condition, a higher GSH content is present compared to euthyroid animals because they have enhanced $\gamma$-GCS activity.

Other studies, using amphibians and mammals, provide evidence for a relationship between thyroid hormones and their immune systems $(28 ; 31 ; 93 ; 145)$. In zebra fish, the thyroid state participates in thymus development and lymphopoiesis (80). It is well documented that in humans and other mammals, clinical hyperthyroidism increased the size and cellularity of the thymus, in particular a larger number of thymus nurse cells, Thy $1^{+}$thymocytes, and the CD4-CD8- and CD44-positive cells $(115 ; 140)$. Hyperthyroidism increases the number of T cells in the spleen and thymus, with high levels of NK cells only in the spleen (145). Meanwhile, there are reports that hypothyroidism reduces cellularity in the spleen and thymus (16). However, in neonatal hypothyroidism, it has been observed that NK cells and regulatory $\mathrm{T}$ cells $\left(\mathrm{CD} 4{ }^{+} \mathrm{CD} 25^{+}\right)$are enhanced in the thymus, spleen, and peripheral blood. The dendritic cells integrate signals from several pathways and receptors, including those 
arising from engaging in uptake and pattern recognition receptors, proinflammatory and antiinflammatory cytokines, chemokines, and hormones like THs. $\mathrm{T}_{3}$ promotes dendritic-cell maturation and Th1-type cytokine secretion (88). The dendritic cells are modulated by the THs because the $\mathrm{T}_{3}$-TRb1 causes Akt signaling-pathway activation and NFkB-dependence, but also a PI3K-independent pathway (89).

Because hypothyroidism is a condition related with both decreased immune system activity and increased infection in humans $(4 ; 116)$, this state could be protective in the case of toxicantcaused oxidative stress and cell damage. For example, aniline, an aromatic amine that it is used extensively as an industrial chemical, causes toxicity to the hematopoietic system. Aniline toxicity is generally characterized by methemoglobinemia, hemolytic anemia or hemolysis, and by the development of spleen hyperplasia, fibrosis, and a variety of primary sarcomas following chronic exposure in rats. The immunological system participates actively in aniline-caused oxidative stress and spleen damage $(48 ; 142 ; 143)$. Interestingly, we found that hypothyroid rats had decreased ROS concentration, and lipid peroxidation, but a higher GSH level. Also, the lymphocyte counts $/ \mathrm{mm}^{3}$ in aniline-treated hypothyroid rats was lower compared with euthyroid rats. Therefore, these results suggest that the mild immunosuppression that results from a hypothyroid state may participate in cellular protection. Further investigation is necessary to clarify the roles, risks, and benefits of a hypothyroid state.

\section{ACKNOWLEDGMENT}

This study was partially supported by SIP-IPN 20110336, 20121260, 20131139, 20130956, and 20131118. O-B R, F-C M, C-E E are fellows of SNI, EDI and COFFA. T-M P is fellows of CONACyT and PIFI-COFFA-IPN. Thank you to Carolyn Unck for correcting our English manuscript.

\section{References}

[1] M. Adams, C. Matthews, T.N. Collingwood, Y. Tone, P. Beck-Peccoz, K.K. Chatterjee, Genetic analysis of 29 kindreds with generalized and pituitary resistance to thyroid hormone. Identification of thirteen novel mutations in the thyroid hormone receptor beta gene, Journal of Clinical Investigation, 94 (1994), 506-515.

[2] C. Almeida, M.A. Brasil, A.J. Costa, F.A. Reis, V. Reuters, P. Teixeira, M. Ferreira, A.M. Marques, B.A. Melo, L.B. Teixeira, A. Buescu, M. Vaisman, Subclinical hypothyroidism: psychiatric disorders and symptoms, Revista Brasileira de Psiquiatria, 29 (2007), 157-159.

[3] B. Alt, O.A. Elsalini, P. Schrumpf, N. Haufs, N.D. Lawson, G.C. Schwabe, S. Mundlos, A. Gruters, H. Krude, K.B. Rohr, Arteries define the position of the thyroid gland during its developmental relocalisation, Development, 133 (2006), 3797-3804. 
[4] K. Amadi, A.M. Sabo, O.O. Ogunkeye, F.S. Oluwole, Thyroid hormone: a "prime suspect" in human immunodeficiency virus (HIV/AIDS) patients?, Nigerian Journal of Physiological Sciences, 23 (2008), 61-66.

[5] S. Andersen, N.H. Bruun, K.M. Pedersen, P. Laurberg, Biologic variation is important for interpretation of thyroid function tests, Thyroid, 13 (2003), 1069-1078.

[6] S. Andersen, K.M. Pedersen, N.H. Bruun, P. Laurberg, Narrow Individual Variations in Serum T4 and T3 in Normal Subjects: A Clue to the Understanding of Subclinical Thyroid Disease, Journal of Clinical Endocrinology and Metabolism, 8 (2002)7, 1068-1072.

[7] L. Andersson, J. Westerlund, S. Liang, T. Carlsson, E. Amendola, H. Fagman, M. Nilsson, Role of EphA4 Receptor Signaling in Thyroid Development: Regulation of Folliculogenesis and Propagation of the C-Cell Lineage, Endocrinology, 152 (2011), 1154-1164.

[8] S. Arancibia, L. Tapia-Arancibia, H. Astier, I. Assenmacher, Physiological evidence for alpha 1-adrenergic facilitatory control of the cold-induced TRH release in the rat, obtained by push-pull cannulation of the median eminence, Neuroscience Letters, 100 (1989), 169-174.

[9] A.R. Ayala, M.D. Danese, P.W. Ladenson, When to treat mild hypothyroidism, Endocrinology Metabolism Clinical North Am, 29 (2000), 399-415.

[10] M.F. Azevedo, G.B. Barra, L.A. Naves, L.F. Ribeiro Velasco, P. Godoy Garcia Castro, L.C.G. de Castro, A.A. Amato, A. Miniard, D. Driscoll, L. Schomburg, F. de Assis Rocha Neves, Selenoprotein-Related Disease in a Young Girl Caused by Nonsense Mutations in the SBP2 Gene, Journal of Clinical Endocrinology and Metabolism, 95 (2010), 4066-4071.

[11] U. Bandyopadhyay, K. Biswas, R.K. Banerjee, Extrathyroidal actions of antithyroid thionamides, Toxicology Letters, 128 (2002), 117-127.

[12] S. Basaria, D.S. Cooper, Amiodarone and the thyroid, American Journal of Medicine, 118 (2005), 706-714. 
[13] J.H. Bassett, C.B. Harvey, G.R. Williams, Mechanisms of thyroid hormone receptorspecific nuclear and extra nuclear actions. Molecular and Cellular Endocrinology 213 (2003), 1-11.

[14] P. Beck-Peccoz, V.K. Chatterjee, The variable clinical phenotype in thyroid hormone resistance syndrome, Thyroid 4 (1994), 225-232.

[15] P. Beck-Peccoz, V.K. Chatterjee, W.W. Chin, L.J. DeGroot, J.L. Jameson, H. Nakamura, S. Refetoff, S.J. Usala, B.D. Weintraub, Nomenclature of thyroid hormone receptor beta gene mutations in resistance to thyroid hormone: consensus statement from the First Workshop on Thyroid Hormone Resistance, 10-11 July 1993, Cambridge, UK. Clinical Endocrinology (Oxf), 40 (1994), 697-700.

[16] G.D. Bendyug, Y.A. Grinevich, N.N. Khranovskaya, F.V. Fil'chakov, L.G. Yugrinova, A.G. Kad'kalenko, The state of the immune system in thyroidectomized rats, Bulletin of Experimental Biology and Medicine, 135 (2003), 154-157.

[17] J. Bernal, Action of thyroid hormone in brain, Journal of Endocrinology Investigation, 25 (2002), 268-288.

[18] J. Bernal, Thyroid hormone resistance syndromes, Endocrinología y Nutrición, 58 (2011), 185-196.

[19] B. Biondi, D.S. Cooper, The Clinical Significance of Subclinical Thyroid Dysfunction, Endocrine Reviews, 29 (2008), 76-131.

[20] I. Bobadilla, M. Franco, D. Cruz, J. Zamora, S.G. Robles, E. Chavez, Hypothyroidism protects the myocardium against ischemia-reperfusion injury, Archivos de Cardiología de México, 72 (2002) Suppl 1, S27-S30.

[21] E. Bochukova, N. Schoenmakers, M. Agostini, E. Schoenmakers, O. Rajanayagam, J.M. Keogh, E. Henning, J. Reinemund, E. Gevers, M. Sarri, K. Downes, A. Offiah, A. Albanese, D. Halsall, J.W. Schwabe, M. Bain, K. Lindley, F. Muntoni, F. VarghaKhadem, F.V. Khadem, M. Dattani, I.S. Farooqi, M. Gurnell, K. Chatterjee, A mutation in the thyroid hormone receptor alpha gene, New England Journal of Medicine, 366 (2012), 243-249. 
[22] M.C. Browning, W.M. Bennet, A.J. Kirkaldy, R.T. Jung, Intra-individual variation of thyroxin, triiodothyronine, and thyrotropin in treated hypothyroid patients: implications for monitoring replacement therapy, Clinical Chemistry, 34 (1988), 696-699.

[23] R Bruck, S Weiss, A Traister, I Zvibel, H Aeed, Z Halpern, R Oren, Induced hypothyroidism accelerates the regression of liver fibrosis in rats, Journal of Gastroenterology and Hepatology, 22 (2007), 2189-2194.

[24] B.K. Budenhofer, N. Ditsch, U. Jeschke, R. Gartner, B. Toth, Thyroid dys-function in normal and disturbed pregnancy, Archives of Gynecology and Obstetrics, (2012).

[25] F. Calaciura, G. Mendorla, M. Distefano, S. Castorina, T. Fazio, R.M. Motta, L. Sava, F. Delange, R. Vigneri, Childhood IQ measurements in infants with transient congenital hypothyroidism, Clinical Endocrinology (Oxf,) 43(1995), 473-477.

[26] C. Calanas, M. Espinosa, G. Manzano-Garcia, R. Santamaria, F. Lopez-Rubio, P. Aljama, Necrotizing glomerulonephritis and pulmonary hemorrhage associated with carbimazole therapy, Thyroid, 15 (2005), 286-288.

[27] D. Calebiro, T. de Filippis, S. Lucchi, C. Covino, S. Panigone, P. Beck-Peccoz, Dunlap, L. Persani, Intracellular entrapment of wild-type TSH receptor by oligomerization with mutants linked to dominant TSH resistance, Human Molecular Genetics, 14 (2005), 2991-3002.

[28] E. Cano-Europa, V. Blas-Valdivia, M Franco-Colin, C.A. Gallardo-Casas, R. OrtizButron, Methimazole-induced hypothyroidism causes cellular damage in the spleen, heart, liver, lung and kidney, Acta Histochemica, 113 (2011), 1-5.

[29] E. Cano-Europa, V. Blas-Valdivia, G.E Lopez-Galindo, M. Franco-Colin, M. Pineda-Reynoso, A. Hernandez-Garcia, R. Ortiz-Butron, Methimazole-induced hypothyroidism causes alteration of the REDOX environment, oxidative stress, and hepatic damage; events not caused by hypothyroidism itself, Annals of Hepatology, 9 (2010), 80-88.

[30] C. Carella, G. Mazziotti, G. Amato, L.E. Braverman, E. Roti. Interferon-\{alpha\}Related Thyroid Disease, Pathophysiological, Epidemiological, and Clinical Aspects, Journal of Clinical Endocrinology and Metabolism, 89 (2004), 3656-3661. 
[31] S. Casallo Blanco, M.A. Valero, F. Marcos Sanchez, L. de Matias Salces, J.J. Blanco Gonzalez, MJ Martin Barranco, Methimazole and propylthiouracil induced acute toxic hepatitis, Gastroenterology and Hepatology, 30(2007), 268-270.

[32] E. Chavez, M. Franco, H. Reyes-Vivas, C Zazueta, J. Ramirez, R. Carrillo, Hypothyroidism renders liver mitochondria resistant to the opening of membrane permeability transition pore, Biochimica et Biophysica Acta, 1407 (1998), 243-248.

[33] S.Y. Cheng, Multiple mechanisms for regulation of the transcriptional activity of thyroid hormone receptors, Reviews in Endocrine and Metabolic Disorders, 1 (2000), 9-18.

[34] S.Y. Cheng, J.L. Leonard, P.J .Davis, Molecular Aspects of Thyroid Hormone Actions, Endocrine Reviews, 31 (2010), 139-170.

[35] M.I. Chiamolera, F.E. Wondisford, Minireview, Thyrotropin-Releasing Hormone and the Thyroid Hormone Feedback Mechanism, Journal of Clinical Endocrinology and Metabolism, 94 (2009), 1472-147a.

[36] J.W. Chu, L.M. Crapo, The Treatment of Subclinical Hypothyroidism Is Seldom Necessary, Journal of Clinical Endocrinology and Metabolism, 86 (2001), 45914599.

[37] D.S. Cooper, Clinical practice, Subclinical hypothyroidism, New England Journal of Medicine, 345 (2001), 260-265.

[38] A.L. Daliva, B. Linder, J. DiMartino-Nardi, P. Saenger, Three-year follow-up of borderline congenital hypothyroidism, Journal of Pediatrics, 136 (2000), 53-56.

[39] C. Di Cosmo, N. McLellan, X. Liao, K.K. Khanna, R.E. Eiss, L. Papp, S. Refetoff, Clinical and Molecular Characterization of a Novel Selenocysteine Insertion Sequence-Binding Protein 2 (SBP2) Gene Mutation (R128X), Journal of Clinical Endocrinology and Metabolism, 94 (2009), 4003-4009.

[40] C. Di-Cosmo, X.H. Liao, A.M. Dumitrescu, R.E. Weiss, S. Refetoff, A Thyroid Hormone Analog with Reduced Dependence on the Monocarboxylate Transporter 8 for Tissue Transport, Endocrinology, 150 (2009), 4450-4458. 
[41] D.M. Driscoll, P.R. Copeland, Mechanism and regulation of selenoprotein synthesis, Annual Review of Nutrition, 23 (2003), 17-40.

[42] A.M. Dumitrescu, X.H. Liao, T.B. Best, K. Brockmann, S. Refetoff, A novel syndrome combining thyroid and neurological abnormalities is associated with mutations in a monocarboxylate transporter gene, American Journal of Human Genetics, 74 (2004), 168-175.

[43] A.M. Dumitrescu, S. Refetoff, The syndromes of reduced sensitivity to thyroid hormone, Biochimica et Biophysica Acta, 1830 (2013), 3987-4003.

[44] A.M. Dumitrescu, X.H. Liao, M.S. Abdullah, J. Lado-Abeal, F.A. Majed, L.C. Moeller, G. Boran, L. Schomburg, R.E. Weiss, S. Rfetoff, Mutations in SECISBP2 result in abnormal thyroid hormone metabolism. Nature Genetics 37 (2005), 12471252.

[45] R. Ekins, The free hormone hypothesis and measurement of free hormones, Clinical Chemistry, 38 (1992), 1289-1293.

[46] E.A. Eugster, D. LeMay, J.M. Zerin, O.H. Pescovitz, Definitive diagnosis in children with congenital hypothyroidism, Journal of Pediatrics, 144 (2004), 643-647.

[47] H. Fagman, M. Nilsson, Morphogenesis of the thyroid gland, Molecular and Cellular Endocrinology, 323 (2010), 35-54.

[48] X. Fan, J. Wang, K.V. Soman, G.A. Ansari, M.F. Khan, Aniline-induced nitrosative stress in rat spleen: proteomic identification of nitrated proteins, Toxicology and Applied Pharmacology, 255 (2011), 103-112.

[49] V. Fatourechi, Subclinical hypothyroidism: an update for primary care physicians, Mayo Clinic Proceedings, 84 (2009), 65-71.

[50] C. Fekete, R.M. Lechan, Neuroendocrine implications for the association between cocaine- and amphetamine regulated transcript (CART) and hypophysiotropic thyrotropin-releasing hormone (TRH), Peptides, 27 (2006), 2012-2018. 
[51] C. Fekete, J. Kelly, E. Mihaly, S. Sarkar, W.M. Rand, G. Legradi, C.H Emerson, R.M. Lechan, Neuropeptide Y Has a Central Inhibitory Action on the HypothalamicPituitary-Thyroid Axis, Endocrinology, 142 (2001), 2606-2613.

[52] E. Fliers, U.A Unmehopa, A. Alkemade, Functional neuroanatomy of thyroid hormone feedback in the human hypothalamus and pituitary gland, Molecular and Cellular Endocrinology, 251 (2006), 1-8.

[53] E.CH. Friesema, S. Ganguly, A. Abdalla, J.E.M. Fox, A.P. Halestrap, T.J. Visser, Identification of Monocarboxylate Transporter 8 as a Specific Thyroid Hormone Transporter, Journal of Biological Chemistry, 278 (2003), 40128-40135.

[54] H. Gharib, R.M. Tuttle, H.J. Baskin, L.H Fish, P.A. Singer, M.T. McDermott, Subclinical Thyroid Dysfunction: A Joint Statement on Management from the American Association of Clinical Endocrinologists, the American Thyroid Association, and The Endocrine Society, Journal of Clinical Endocrinology and Metabolism, 90 (2005), 581-585.

[55] A.D. Gika, A. Siddiqui, A.J. Hulse, S. Edward, P. Fallon, M.E. McEntagart, W. Jan, D. Josifova, T. Lerman-Sagie, J. Drummond, E. Thompson, S. Refetoff, C.G. Bonnemann, H. Jungbluth, White matter abnormalities and dystonic motor disorder associated with mutations in the SLC16A2 gene, Developmental Medicine and Child Neurology, 52 (2010), 475-482.

[56] D. Glinoer, The Regulation of Thyroid Function in Pregnancy: Pathways of Endocrine Adaptation from Physiology to Pathology, Endocrine Reviews, 18 (1997), 404-433.

[57] H. Grasberger, S. Refetoff, Genetic causes of congenital hypothyroidism due to dyshormonogenesis, Current Opinion in Pediatrics, 23 (2011), 421-428.

[58] A.P. Halestrap, S.J. Clarke, S.A. Javadov, Mitochondrial permeability transition pore opening during myocardial reperfusion--a target for cardioprotection, Cardiovascular Research, 61 (2004), 372-385.

[59] B. Halliwell, J. Gutteridge, Free radicals in biology and medicine, Oxford: Oxford University Press (2007). 
[60] T. Hamajima, Y. Mushimoto, H. Kobayashi, Y. Saito, K. Onigata, Novel compound heterozygous mutations in the SBP2 gene: characteristic clinical manifestations and the implications of $\mathrm{GH}$ and triiodothyronine in longitudinal bone growth and maturation, European Journal of Endocrinology, 166 (2012), 957.

[61] S. Harvey, Thyrotrophin-releasing hormone: a growth hormone-releasing factor, Journal of Endocrinology, 125 (1990), 345-358.

[62] M. Helfand, C.C. Redfern, Clinical guideline, part 2, Screening for thyroid disease: an update, American College of Physicians, Annals of Internal Medicine, 129 (1998), 144-158.

[63] G. Hennemann, R. Docter, E.CH. Friesema, M. de Jong, E.P. Krenning, T.J. Visser, Plasma Membrane Transport of Thyroid Hormones and Its Role in Thyroid Hormone Metabolism and Bioavailability, Endocrine Reviews, 22 (2001), 451-476.

[64] P. Hermanns, H. Grasberger, R. Cohen, C. Freiberg, H.G. Dorr, S. Refetoff, J. Pohlenz, Two Cases of Thyroid Dysgenesis Caused by Different Novel PAX8 Mutations in the DNA Binding Region: In vitro studies reveal different pathogenic mechanisms, Thyroid, (2012).

[65] P. Hermanns, H. Grasberger, S. Refetoff, J. Pohlenz, Hypothyroidism in a Girl with Thyroid Dysgenesis Due to Mutations in the NKX2.5 Gene and the PAX8 Promoter, Endocrine Reviews, 32 (2011), 2-56.

[66] P. Hermanns, H. Grasberger, S. Refetoff, J. Pohlenz, Mutations in the NKX2.5 Gene and the PAX8 Promoter in a Girl with Thyroid Dysgenesis, Journal of Clinical Endocrinology and Metabolism, 96 (2011), E977-E981.

[67] H. Heuer, M.K. Maier, S. Iden, J. Mittag, E.CH. Friesema, T.J. Visser, K. Bauer, The Monocarboxylate Transporter 8 Linked to Human Psychomotor Retardation Is Highly Expressed in Thyroid Hormone-Sensitive Neuron Populations, Endocrinology, 146 (2005), 1701-1706.

[68] A.N. Hollenberg, D. Forrest, The thyroid and metabolism: the action continues, Cell Metabolism, 8 (2008), 10-12. 
[69] A.N. Hollenberg, T. Monden, F.E. Wondisford, Ligand-independent and -dependent Functions of Thyroid Hormone Receptor Isoforms Depend upon Their Distinct Amino Termini, Journal of Biological Chemistry, 270 (1995), 14274-14280.

[70] S. Horn, S. Kersseboom, S. Mayerl, J. Muller, C. Groba, M. Trajkovic-Arsic, T. Ackermann, T.J. Visser, H. Heuer, Tetrac Can Replace Thyroid Hormone During Brain Development in Mouse Mutants Deficient in the Thyroid Hormone Transporter Mct8, Endocrinology, 154 (2013), 968-979.

[71] C. Hwang, A.J. Sinskey, H.F. Lodish, Oxidized redox state of glutathione in the endoplasmic reticulum, Science, 257 (1992), 1496-1502.

[72] B. Jemec, Studies of the tumorigenic effect of two goitrogens, Cancer, 40 (1977), 2188-2202.

[73] D.P. Jones, E. Maellaro, S. Jiang, A.F. Slater, S. Orrenius, Effects of N-acetyl-Lcysteine on T-cell apoptosis are not mediated by increased cellular glutathione, Immunology Letters, 45 (1995), 205-209.

[74] J. Kapustin, Hypothyroidism, An evidence-based approach to a complex disorder, The nurse practitional, 35 (2010), 44-53.

[75] S. Kersseboom, T.J. Visser, Tissue-specific effects of mutations in the thyroid hormone transporter MCT8, Arquivos Brasileiros de Endocrinologia e Metabologia, 55 (2011), 1-5.

[76] A. Kinne, S. Roth, H. Biebermann, J. Kohrle, Gruters, U. Schweizer, Surface translocation and tri-iodothyronine uptake of mutant MCT8 proteins are cell typedependent, Journal of Molecular Endocrinology, 43 (2009), 263-271.

[77] R.J. Koenig, Regulation of type 1 iodothyronine deiodinase in health and disease, Thyroid, 15 (2005), 835-840.

[78] S.H. Lafranchi, J.E. Haddow, J.G. Hollowell: Is thyroid inadequacy during gestation a risk factor for adverse pregnancy and developmental outcomes?, Thyroid, 15 (2005), 60-71. 
[79] S.H. Lafranchi, D.B. Snyder, D.E. Sesser, M.R. Skeels, N. Singh, G.A. Brent, J.C. Nelson, Follow-up of newborns with elevated screening T4 concentrations, Journal of Pediatrics, 143 (2003), 296-301.

[80] S.H. Lam, Y.M. Sin, Z. Gong, T.J. Lam, Effects of thyroid hormone on the development of immune system in zebrafish, General and Comparative Endocrinology, 142 (2005), 325-335.

[81] L.H. Lash, Mitochondrial glutathione transport: physiological, pathological and toxicological implications, Chemico-Biological Interactions, 163 (2006), 54-67.

[82] W.K. Liu, T.B. Ng, Effect of methimazole-induced hypothyroidism on alveolar macrophages, Virchows Archiv. B, Cell Pathology Including Molecular Pathology, 60 (1991), 21-26.

[83] R.J. Lock, N.A. Marden, H.J. Kemp, P.H. Thomas, D.J. Goldie, M.M. Gompels, Subclinical hypothyroidism: a comparison of strategies to achieve adherence to treatment guidelines, Annals of Clinical Biochemistry, 41 (2004), 197-200 .

[84] P.E. Macchia, Y. Takeuchi, T. Kawai, K. Cua, K. Gauthier, O. Chassande, H. Seo, Y Hayashi, J. Samarut, Y Murata, R.E. WEISS, S. Refetoff, Increased sensitivity to thyroid hormone in mice with complete deficiency of thyroid hormone receptor \{alpha\}, PNAS, 98 (2001), 349-354.

[85] F. Mahjoubi, M.M. Mohammadi, M Montazeri, M. Aminii, M. Hashemipour, Mutations in the gene encoding paired box domain (PAX8) are not a frequent cause of congenital hypothyroidism $(\mathrm{CH})$ in Iranian patients with thyroid dysgenesis, Arquivos Brasileiros de Endocrinologia e Metabologia, 54 (2010), 555-559.

[86] A.L. Maia, I.M. Goemann, E.L.S. Meyer, S.M. Wajner, Type 1 iodothyronine deiodinase in human physiology and disease: Deiodinases: the balance of thyroid hormone, Journal of Endocrinology, 209 (2011), 283-297.

[87] A.L. Maia, B.W. Kim, S.A. Huang, J.W. Harney, P.R. Larsen, Type 2 iodothyronine deiodinase is the major source of plasma T3 in euthyroid humans, Journal of Clinical Investigation, 115 (2005), 2524-2533. 
[88] I. Mascanfroni, M. del Mar Montesinos, S. Susperreguy, C. Cervi, J. Ilarregui, V. Ramseyer, C. Pellizas: Control of dendritic cell maturation and function by triiodothyronine, The FASEB Journal, 22 (2008), 1032-1042.

[89] I.D. Mascanfroni, M. del Mar Montesinos, V.A. Alamino, S. Susperreguy, J.P. Nicola, J.M. Ilarregui, A.M. Masini-Repiso, G.A. Rabinovich, C.G. Pellizas: Nuclear Factor (NF)-\{kappa\}B-dependent Thyroid Hormone Receptor \{beta 1 Expression Controls Dendritic Cell Function via Akt Signaling, Journal of Biological Chemistry, 285 (2010), 9569-9582.

[90] M.T. McDermott, E.C. Ridgway, Subclinical Hypothyroidism Is Mild Thyroid Failure and Should be Treated, Journal of Clinical Endocrinology and Metabolism, 86 (2001), 4585-4590.

[91] A. Milanesi, G.A. Brent, Management of hypothyroidism in pregnancy, Current Opinion in Endocrinology, Diabetes, and Obesity, 18 (2011), 304-309.

[92] L.C. Moeller, S. Kimura, T. Kusakabe, X.H. Liao, J. Van Sande, S. Refetoff, Hypothyroidism in Thyroid Transcription Factor 1 Haploinsufficiency Is Caused by Reduced Expression of the Thyroid-Stimulating Hormone Receptor, Molecular Endocrinology, 17 (2003), 2295-2302.

[93] R. Nakamura, R. Teshima, A. Hachisuka, Y. Sato, K. Takagi, R. Nakamura, G.H. Woo, M. Shibutani, J. Sawada, Effects of developmental hypothyroidism induced by maternal administration of methimazole or propylthiouracil on the immune system of rats, International Immunopharmacology, 7 (2007), 1630-1638.

[94] E.A. Nillni, C Vaslet, M. Harris, A. Hollenberg, C. Bjorbak, J.S. Flier, Leptin Regulates Prothyrotropin-releasing Hormone Biosynthesis, Evidence for direct and indirect pathways, Journal of Biological Chemistry, 275 (2000), 36124-36133.

[95] R. Ortiz-Butron, V. Blas-Valdivia, M. Franco-Colin, M. Pineda-Reynoso, E. CanoEuropa, An increase of oxidative stress markers and the alteration of the antioxidant enzymatic system are associated with spleen damage caused by methimazoleinduced hypothyroidism, Drug and Chemical Toxicology, 34 (2011), 180-188.

[96] M.S. Paller, Hypothyroidism protects against free radical damage in ischemic acute renal failure, Kidney International, 29 (1986), 1162-1166. 
[97] A. Papadimitriou, A.M. Dumitrescu, A. Papavasiliou, A. Fretzayas, P. Nicolaidou, S. Refetoff, A Novel Monocarboxylate Transporter 8 Gene Mutation as a Cause of Severe Neonatal Hypotonia and Developmental Delay, Pediatrics, 121 (2008), e199e202.

[98] G. Paradies, G. Petrosillo, F.M. Ruggiero, Cardiolipin-dependent decrease of cytochrome c oxidase activity in heart mitochondria from hypothyroid rats, Biochimica et Biophysica Acta, 1319 (1997), 5-8.

[99] G. Paradies, F.M. Ruggiero, G. Petrosillo, E. Quagliariello, Enhanced cytochrome oxidase activity and modification of lipids in heart mitochondria from hyperthyroid rats, Biochim Biophys Acta, 1225 (1994), 165-170.

[100] E.N. Pearce, L.E. Braverman, Environmental pollutants and the thyroid, Best Practice and Research. Clinical Endocrinology and Metabolism, 23 (2009), 801-813.

[101] L. Persani, D. Calebiro, D. Cordella, G. Weber, G. Gelmini, D. Libri, T. de Filippis, M. Bonomi, Genetics and phenomics of hypothyroidism due to TSH resistance, Molecular and Cellular Endocrinology, 322 (2010), 72-82.

[102] M.V. Rastogi, S.H. Lafranchi, Congenital hypothyroidism, Orphanet Journal of Rare Disease, 5 (2010), 17.

[103] J. Raymond, S.H. Lafranchi, Fetal and neonatal thyroid function: review and summary of significant new findings, Current Opinion in Endocrinology, Diabetes, and Obesity, 17 (2010), 1-7.

[104] M. Rebai, I. Kallel, A. Rebai, Genetic features of thyroid hormone receptors. Journal of Genetics, 91 (2012), 367-374.

[105] S. Refetoff, L.T. Dewind, L.J. Egroot, Familial Syndrome Combining Deaf-Mutism, Stippled Epiphyses, Goiter and Abnormally High PBI, Possible Target Organ Refractoriness to Thyroid Hormone, Journal of Clinical Endocrinology and Metabolism, 27 (1967), 279-294.

[106] S. Refetoff, A.M. Dumitrescu, Syndromes of reduced sensitivity to thyroid hormone: genetic defects in hormone receptors, cell transporters and deiodination, Best Practice and Research in Clinical Endocrinology and Metabolism, 21 (2007), 277305. 
[107] S. Refetoff, V.S. Marinov, H. Tunca, M.M. Byrne, T. Sunthornthepvarakul, R.E. Weiss, A new family with hyperthyroxinemia caused by transthyretin Val109 misdiagnosed as thyrotoxicosis and resistance to thyroid hormone. A clinical research center study, Journal of Clinical Endocrinology and Metabolism. 81 (1996), 3335-3340.

[108] S. Refetoff, R.E. Weiss, S.J. Sala, The Syndromes of Resistance to Thyroid Hormone, Endocrine Reviews, 14 (1993), 348-399.

[109] S. Reutrakul, P.M. Sadow, S. Pannain, J. Pohlenz, G.A. Carvalho, P.E. Macchia, R.E. Weiss, S. Refetoff, Search for Abnormalities of nuclear corepressors, coactivators, and a coregulator in families with Resistance to Thyroid Hormone without mutations in thyroid hormone receptor $\{$ beta\} or $\{$ alpha\} genes, Journal of Clinical Endocrinology and Metabolism, 85 (2000), 3609-3617.

[110] C.G. Roberts, P.W. Ladenson, Hypothyroidism, Lancet, 363 (2004), 793-803.

[111] P.M. Sadow, S. Reutrakul, R.E. Weiss, S. Refetoff, Resistance to thyroid hormone in the absence of mutations in the thyroid hormone receptor genes, Current Opinion in Endocrinology \& Diabetes, 7 (2000), 253-259.

[112] N.A. Samaan, BM. Osborne, B. Mackay, M.E. Leavens, T.M. Duello, N.S. Halmi, Endocrine and Morphologic Studies of Pituitary Adenomas Secondary to Primary Hypothyroidism, Journal of Clinical Endocrinology and Metabolism, 45 (1977), 903911.

[113] S. Sarkar, R.M. Lechan, Central administration of Neuropeptide Y reduces \{alpha\}melanocyte-stimulating hormone-induced cyclic adenosine 5'-monophosphate response element binding protein (CREB) phosphorylation in pro-thyrotropinreleasing hormone neurons and increases CREB phosphorylation in corticotropinreleasing hormone neurons in the hypothalamic paraventricular nucleus, Endocrinology, 144 (2003), 281-291.

[114] F.Q. Schafer, G.R. Buettner, Redox environment of the cell as viewed through the redox state of the glutathione disulfide/glutathione couple, Free Radic Biology and Medicine, 30 (2001), 1191-1212.

[115] J.M. Scheiff, A.C. Cordier, S. Haumont, Epithelial cell proliferation in thymic hyperplasia induced by triiodothyronine, Clinical and Experimental Immunology, 27 (1977), 516-521. 
[116] P.S. Schoenfeld, J.W. Myers, L. Myers, J.C. LaRocque, Suppression of cellmediated immunity in hypothyroidism, Southern Medical Journal, 88 (1995), 347349.

[117] E. Schoenmakers, M. Agostini, C. Mitchell, N. Schoenmakers, O. Anayagam, R. Padidela, L. Ceron-Gutierrez, R. Doffinger, C. Prevosto, J. Luan, S. Montano, J. Luan, M. Castanet, N. Clemons, M. Groeneveld, P. Castets, M. Karbaschi, S. Aitken, A. Dixon, J. Williams, I. Campi, M. Blount, H. Burton, F. Muntoni, D. O'Donovan, A. Dean, A. Warren, C. Brierley, D. Baguley, P. Guicheney, R. Fitzgerald, A. Coles, H. Gaston, P. Todd, A. Holmgren, K. Khanna, M. Cooke, R. Semple, D. Halsall, N. Wareham, J. Schwabe, L. Grasso, P. Beck-Peccoz, A. Ogunko, M. Dattani, M. Gurnell, K. Chatterjee, Mutations in the selenocysteine insertion sequence-binding protein 2 gene lead to a multisystem selenoprotein deficiency disorder in humans, Journal of Clinical Investigation, 120 (2010), 4220-4235.

[118] L. Schomburg, K. Bauer, Regulation of the adenohypophyseal thyrotropin-releasing hormone-degrading ectoenzyme by estradiol, Endocrinology, 138 (1997), 35873593.

[119] P. Schonfeld, M.R. Wieckowski, L. Wojtczak, Thyroid hormone-induced expression of the ADP/ATP carrier and its effect on fatty acid-induced uncoupling of oxidative phosphorylation, FEBS Lett, 416 (1997), 19-22.

[120] C.E. Schwartz, R.E. Stevenson, The MCT8 thyroid hormone transporter and AllanHerndon-Dudley syndrome, Best Practice and Research. Clinical Endocrinology and Metabolism, 21 (2007), 307-321.

[121] K. Shibayama, Y. Ohyama, A. Hishinuma, Y. Yokota, K. Kazahari, M. Kazahari, T. Ieiri, N. Matsuura, Subclinical hypothyroidism caused by a mutation of the thyrotropin receptor gene. Pediatrics International, 47 (2005), 105-108.

[122] T. Shiwa, K. Oki, T. Awaya, S. Nakanishi, K. Yamane, Resistance to thyroid hormone accompanied by Graves' disease, Internal Medicine, 50 (2011), 1977-1980.

[123] A. Shuaib, S. Ijaz, S. Hemmings, P. Galazka, R. Ishaqzay, L. Liu, J. Ravindran, H. Miyashita, Decreased glutamate release during hypothyroidism may contribute to protection in cerebral ischemia, Experimental Neurology, 128 (1994), 260-265. 
[124] C. Spitzweg, J.C. Morris, Genetics and phenomics of hypothyroidism and goiter due to NIS mutations, Molecular and Cellular Endocrinology, 322 (2010), 56-63.

[125] J.R. Stockigt, Case finding and screening strategies for thyroid dysfunction, Clinica Chimica Acta, 315 (2002), 111-124.

[126] M.I. Surks, E. Ortiz, G.H. Daniels, C.T. Sawin, N.F. Col, R.H. Cobin, J.A. Franklyn, J.M. Hershman, K.D. Burman, M.A. Denke, C. Gorman, R.S. Cooper, N.J. Weissman, Subclinical thyroid disease: scientific review and guidelines for diagnosis and management, JAMA, 291 (2004), 228-238.

[127] M.I. Surks, J.G. Hollowell, Age-Specific distribution of serum thyrotropin and antithyroid antibodies in the U.S. population: Implications for the prevalence of subclinical hypothyroidism, Journal of Clinical Endocrinology and Metabolism, 92 (2007), 4575-4582.

[128] A. Swaroop, T. Ramasarma, Heat exposure and hypothyroid conditions decrease hydrogen peroxide generation in liver mitochondria, Biochem J, 226 (1985), 403408.

[129] T. Tajima, W. Jo, K. Fujikura, M. Fukushi, K. Fujieda, Elevated free thyroxine levels detected by a neonatal screening system, Pediatrics Research, 66 (2009), 312-316.

[130] V.M. Tenorio-Velazquez, D. Barrera, M. Franco, E. Tapia, R. Hernandez-Pando, O.N. Medina-Campos, J. Pedraza-Chaverri, Hypothyroidism attenuates protein tyrosine nitration, oxidative stress and renal damage induced by ischemia and reperfusion: effect unrelated to antioxidant enzymes activities, BMC Nephrology, 6 (2005), 12.

[131] H. Thonberg, J.M. Fredriksson, J. Nedergaard, B. Cannon, A novel pathway for adrenergic stimulation of cAMP-response-element-binding protein (CREB) phosphorylation: mediation via alphal-adrenoceptors and protein kinase $\mathrm{C}$ activation, Biochemical Journal, 364 (2002), 73-79.

[132] M.H. Tsai, Y.L. Chang, V.C. Wu, C.C. Chang, T.S. Huang, Methimazole-induced pulmonary hemorrhage associated with antimyeloperoxidase-antineutrophil cytoplasmic antibody: a case report, Journal of the Formosan Medical Association, 100 (2001), 772-775. 
[133] W.M. Tunbridge, M.P. Vanderpump, Population screening for autoimmune thyroid disease, Endocrinology and Metabolism Clinics of North America, 29 (2000), 23953.

[134] T. Tutuncu, C. Demirci, U. Gozalan, Y.N. Yuksek, A. Bilgihan, N.A. Kama, Methimazole protects lungs during hepatic ischemia-reperfusion injury in rats: an effect not induced by hypothyroidism, Journal of Gastroenterology and Hepatology, 22(2007), 704-709.

[135] L. Valdivielso, D. Bellido, F. Pulido, F. Hawkins, J. Bernalo, Hipertiroxinemia Disalbuminémica Familiar, Endocrinología, 35 (1988), 19-21.

[136] M. Valko, D. Leibfritz, J. Moncol, M.T. Cronin, M. Mazur, J. Telser, Free radicals and antioxidants in normal physiological functions and human disease, International Journal of Biochemistry and Cell Biology, 39 (2007), 44-84.

[137] A. van Mullem, R. van Heerebeek, D. Chrysis, E. Visser, M Medici, M. Andrikoula, A. Tsatsoulis, R. Peeters, T.J. Visser, Clinical phenotype associated with mutation of thyroid hormone receptor-\{alpha\}1 (TR \{alpha\}1), Endocrine Reviews, 33 (2012), OR26-1.

[138] C. Vaurs-Barriere, M. Deville, C. Sarret, G. Giraud, V. Des Portes, J.M. Prats-Vinas, G. De Michele, B. Dan, A.F. Brady, O. Boespflug-Tanguy, R. Touraine, PelizaeusMerzbacher-Like disease presentation of MCT8 mutated male subjects, Annals of Neurology, 65 (2009), 114-118.

[139] C.F. Verge, D. Konrad, M. Cohen, C. Di Cosmo, A.M. Dumitrescu, T. Marcinkowski, S. Hameed, J. Hamilton, R.E. Weiss, S. Refetoff, Diiodothyropropionic acid (DITPA) in the treatment of MCT8 deficiency, Journal of Clinical Endocrinology \& Metabolism, 97 (2012), 4515-4523.

[140] D.M. Villa-Verde, V. de Mello-Coelho, D.A. Farias-de-Oliveira, M. Dardenne, W. Savino, Pleiotropic influence of triiodothyronine on thymus physiology, Endocrinology, 133 (1993), 867-875.

[141] W.E. Visser, E.CH. Friesema, T.J. Visser, Minireview: Thyroid hormone transporters: the knowns and the unknowns, Molecular Endocrinology, 25 (2011), 114. 
[142] J. Wang, H. Ma, P.J. Boor, V.M. Ramanujam, G.A. Ansari, M.F. Khan, Upregulation of heme oxygenase-1 in rat spleen after aniline exposure, Free Radicical Biology and Medicine, 48 (2010), 513-518.

[143] J. Wang, G Wang, G.A.. Ansari, M.F. Khan, Activation of oxidative stressresponsive signaling pathways in early splenotoxic response of aniline, Toxicology and Applied Pharmacology 230 (2008), 227-234.

[144] L. Wartofsky, R.A. Dickey, The Evidence for a Narrower Thyrotropin Reference Range Is Compelling, Journal of Clinical Endocrinology and Metabolism, 90 (2005), 5483-5488.

[145] K. Watanabe, Y. Iwatani, Y. Hidaka, M. Watanabe, N. Amino, Long-term effects of thyroid hormone on lymphocyte subsets in spleens and thymuses of mice, Endocrine Journal, 42 (1995), 661-668.

[146] A.P. Weetman, Fortnightly review: Hypothyroidism: screening and subclinical disease, BMJ, 314 (1997), 1175.

[147] R.E. Weiss, S. Refetoff, Resistance to thyroid hormone, Review in Endocrine and Metabolic Disorders, 1 (2000), 97-108.

[148] R.E. Weiss, S. Refetoff, Resistance to thyroid hormone (RTH) in the absence of abnormal thyroid hormone receptor (TR) (nonTR-RTH), Hot Endocrinology, 09 (2009).

[149] G. Wittmann, Z. Liposits, R.M. Lechan, C. Fekete, Medullary adrenergic neurons contribute to the neuropeptide Y-ergic innervation of hypophysiotropic thyrotropinreleasing hormone-synthesizing neurons in the rat, Neuroscience Letters, 324 (2002), 69-73.

[150] G. Wittmann, Z. Liposits, R.M. Lechan, C. Fekete, Medullary adrenergic neurons contribute to the cocaine- and amphetamine-regulated transcript-immunoreactive innervation of thyrotropin-releasing hormone synthesizing neurons in the hypothalamic paraventricular nucleus, Brain Research, 1006 (2004), 1-7.

[151] K.A. Woeber, Methimazole-induced hepatotoxicity, Endocrine Practice, 8 (2002), 222-224. 
[152] P.M. Yen, Physiological and Molecular Basis of Thyroid Hormone Action, Physiological Reviews, 81 (2001), 1097-1142. 


\section{High total or free $\mathrm{T}_{4}$}

Normal/high TSH

Rule out levothyroxine therapy, acute not-

thyroidal illness, and drug effects

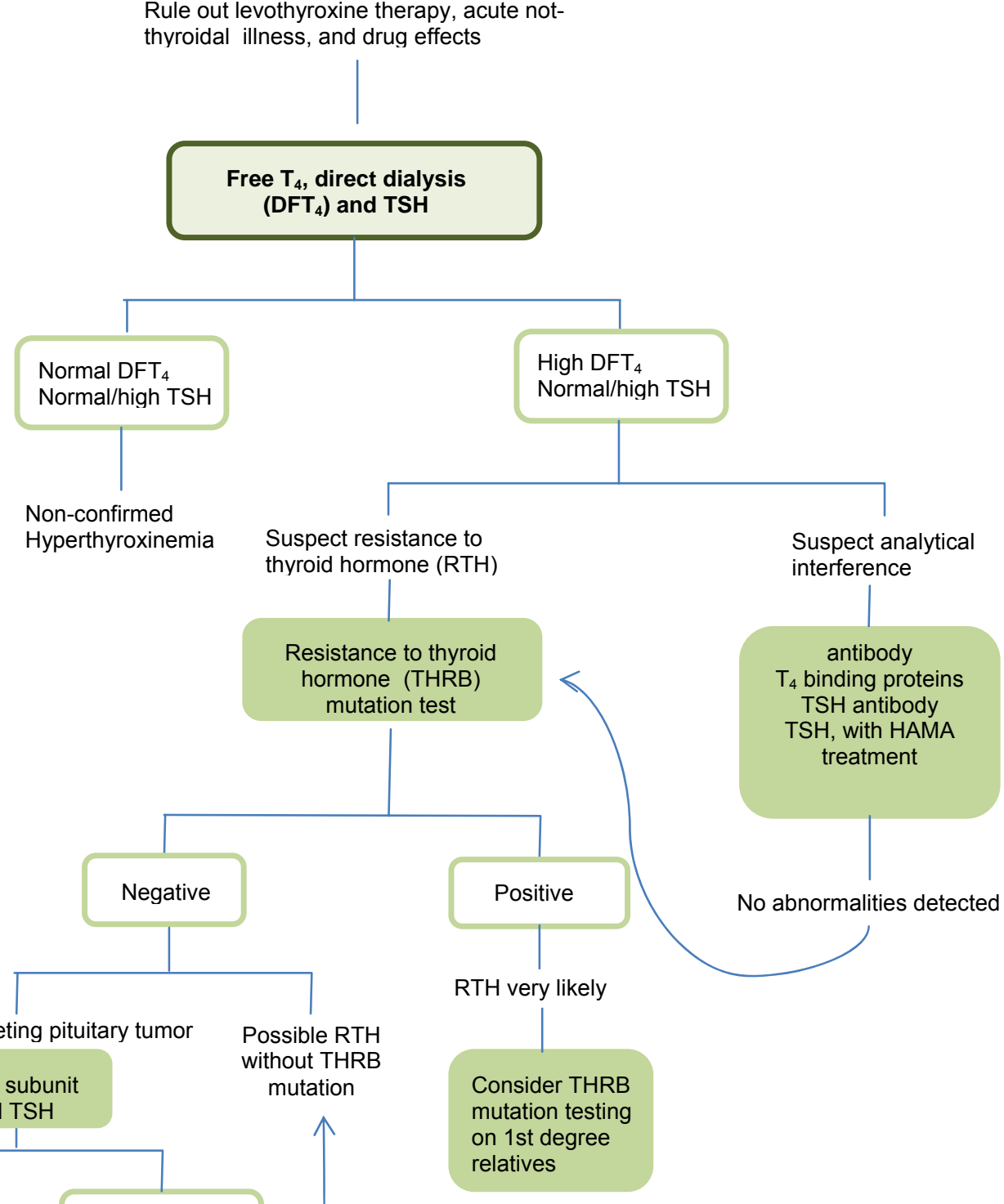

TSH not

suppressed

Possible RTH

Alpha subunit and TSH

Alpha subunit:

TSH ratio $>1$

Pha subunit:

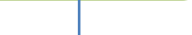

TSH ratio $<1$

$\mathrm{T}_{3}$ suppression test

TSH-secreting

pituitary adenoma

probable

TSH partially suppressed
Figure 1. Screening of RTH.

Adapted from $(14 ; 15 ; 106)$ 


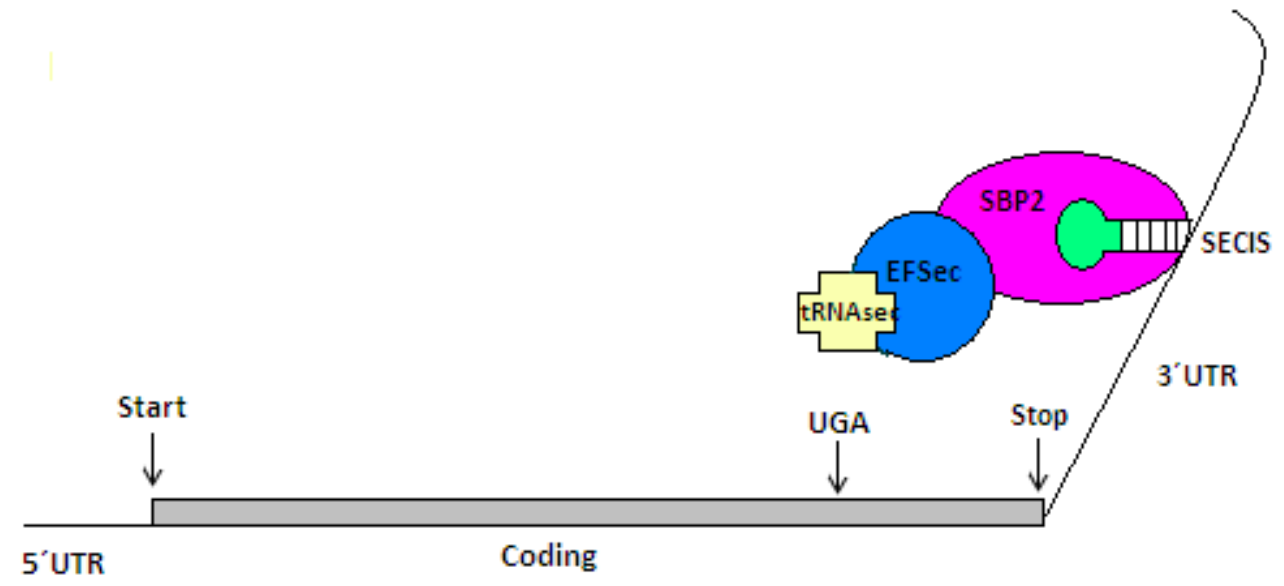

Figure 2. Subclinical hypothyroidism screening $(22 ; 37 ; 49 ; 83 ; 144)$.

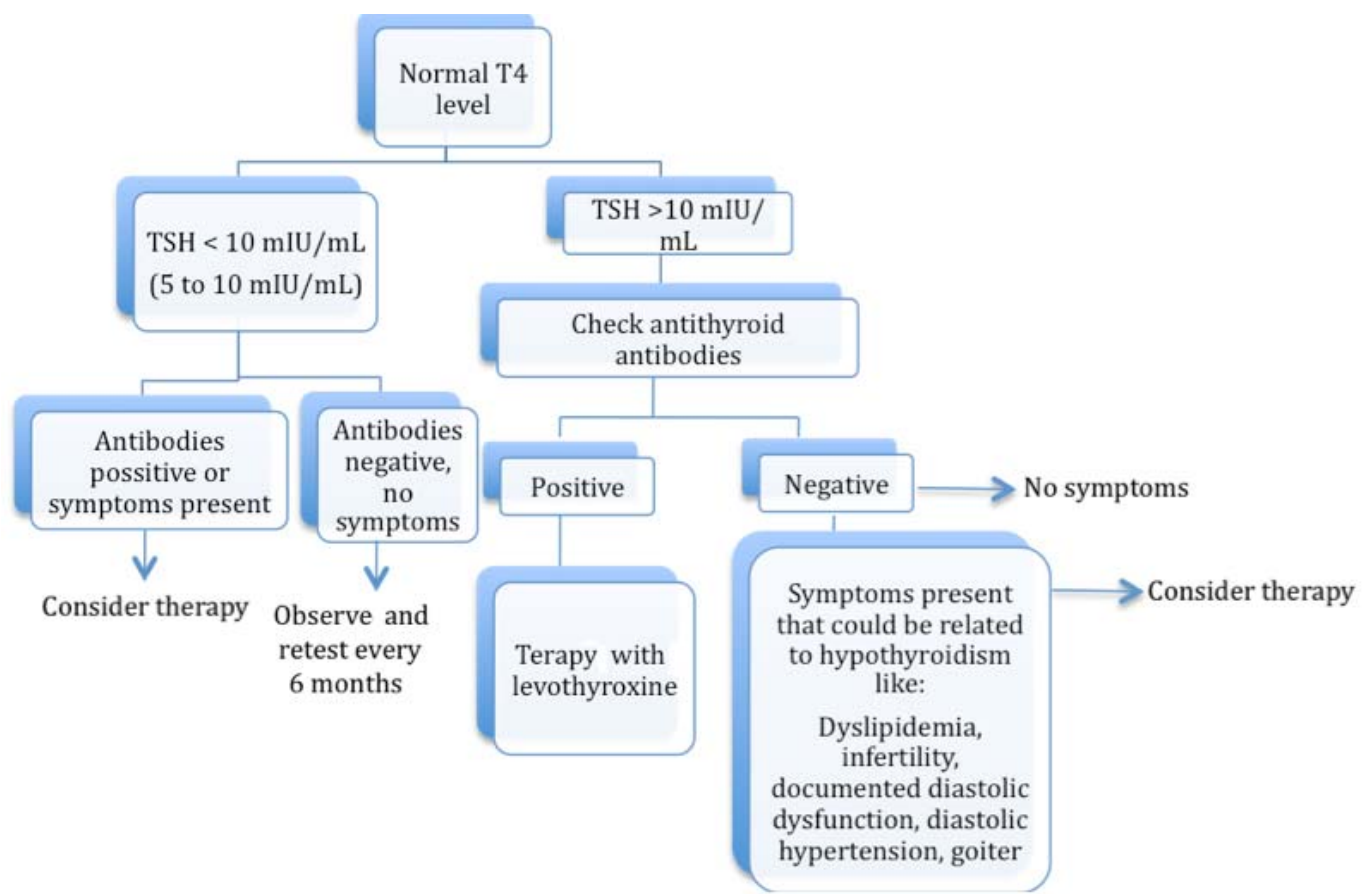

Figure 2. Schematic representation of the components involved in Sec incorporation. Elements present in the mRNA of selenoproteins are an in frame UGA codon and Sec incorporation sequence (SECIS) element, which is a stem loop structure located in the 3'UTR (untranslated region) extreme of the gene. SBP2 binds SECIS and recruits the Sec-specific elongation factor (EFSec) and Sec-specific tRNA (tRNASec) thus resulting in the recoding of the UGA codon and Sec incorporation. Modified from

(43). 
Table 1. Subclinical thyroid diseases classify. Units: mUI/L. *In subclinical hypothyroidism symptoms are proportional to the TSH increase, but not always the case (146).

TSH Tiroxine

Subclinical hypothyroidism

I Grade 3-10 Normal

II Grade $\quad 10.0-20.0 \quad$ Normal

III Grade $\quad>20 \quad$ Normal

Table 2. Serum TSH increases not associated with persistent subclinical hypothyroidism $(19 ; 37)$.

Transient subclinical following sub acute, painless, or postpartum thyroiditis

After withdrawal of thyroid hormone therapy in euthyroid patients

Laboratory analytical problem (assay variability, heterophilic antibodies)

Impaired renal function

Recovery phase of euthyroid sick syndrome

Untreated adrenal insufficiency

TSH-secreting pituitary adenoma

Isolated pituitary resistance to thyroid hormone

Table 3. Mutations in MCT8 gene and protein changes.

\begin{tabular}{|c|c|c|c|c|}
\hline Mutation & Type of mutation & $\begin{array}{l}\text { Position in the } \\
\text { gene }\end{array}$ & Aminoacid change & Reference \\
\hline $\mathrm{N} / \mathrm{S}$ & Missense & Exon 2 & Ala224Val & \\
\hline $\mathrm{N} / \mathrm{S}$ & Missense & Exon 1 & Ala150Val & (47) \\
\hline $\mathrm{N} / \mathrm{S}$ & Missense & Exon 1 & Arg171stop & \\
\hline $\mathrm{N} / \mathrm{S}$ & Missense & Exon 3 & Leu397Pro & \\
\hline c.630insG & Insertion & Exon 1 & $\begin{array}{l}\text { Truncated protein } \\
\text { at codon } 240\end{array}$ & $(48)$ \\
\hline c.630insA & Insertion & Exon 1 & $\begin{array}{l}\text { Truncated protein } \\
\text { at codon } 240\end{array}$ & (49) \\
\hline c.629insA & Insertion/nonsense & Exon 1 & $\begin{array}{l}\text { Premature } \\
\text { termination codon } \\
\text { in exon } 2\end{array}$ & \\
\hline c. $1637 \mathrm{G}>\mathrm{A}$ & Missense & Exon 6 & Gly558Asp & \\
\hline c. $565 \mathrm{ins} \mathrm{ATC}$ & Insertion & Exon 1 & Ins. Ile189 & \\
\hline c. $1703 \mathrm{~T}>\mathrm{C}$ & Missense & Exon 6 & Leu568Pro & \\
\hline c. $1301 \mathrm{~T}>\mathrm{G}$ & Missense & Exon 4 & Leu434Trp & (43) \\
\hline c. $703 \mathrm{G}>\mathrm{A}$ & Missense & Exon 2 & Val235Met & \\
\hline c. $1343 C>A$ & Nonsense & Exon 4 & S448stop & \\
\hline c. $581 \mathrm{C}>\mathrm{T}$ & Missense & Exon 1 & S194F & \\
\hline c. $683 \mathrm{del}$ TCT & Deletion & Exon 2 & Del. F230 & \\
\hline Partial deletion & Deletion & Exons 2-6 & Truncated protein & $(50)$ \\
\hline
\end{tabular}

$\mathrm{N} / \mathrm{S}=$ Non specified 
Table 4. Features of mutations in SBP2 gene

\begin{tabular}{|c|c|c|c|c|c|}
\hline Mutation & Defect & $\begin{array}{l}\text { Amino acid } \\
\text { change }\end{array}$ & $\begin{array}{l}\text { No. of } \\
\text { affected }\end{array}$ & Putative effect & reference \\
\hline c. $1619 \mathrm{G}>\mathrm{A}$ & Homozygous & Arg540Gln & 3 & $\begin{array}{l}\text { Hypomorphic } \\
\text { allele }\end{array}$ & \\
\hline c. $1312 \mathrm{~A}>\mathrm{T}$ & $\begin{array}{l}\text { Compound } \\
\text { heterozygous }\end{array}$ & Lys438stop & 1 & $\begin{array}{l}\text { Missing } \quad \mathrm{C} \\
\text { terminus }\end{array}$ & \\
\hline IVS $8 d s+29 G>A$ & $\begin{array}{l}\text { Compound } \\
\text { heterozygous }\end{array}$ & Frame shift & & $\begin{array}{l}\text { Abnormal } \\
\text { splicing }\end{array}$ & \\
\hline c. $382 \mathrm{C}>\mathrm{T}$ & Homozygous & Arg128stop & 1 & $\begin{array}{l}\text { Smaller } \\
\text { isoforms }\end{array}$ & \\
\hline c. $358 \mathrm{C}>\mathrm{T}$ & $\begin{array}{l}\text { Compound } \\
\text { heterozygous }\end{array}$ & Arg120stop & 1 & $\begin{array}{l}\text { Smaller } \\
\text { isoforms }\end{array}$ & \\
\hline c. $2308 \mathrm{C}>\mathrm{T}$ & & Arg770stop & & $\begin{array}{l}\text { Disrupted } \\
\text { terminus }\end{array}$ & \\
\hline c.668delT & $\begin{array}{l}\text { Compound } \\
\text { heterozygous }\end{array}$ & $\begin{array}{l}\text { Phe223 } \\
\text { frame shift } \\
\text { 255stop }\end{array}$ & 1 & $\begin{array}{l}\text { Truncation and } \\
\text { smaller } \\
\text { isoforms }\end{array}$ & \\
\hline $\begin{array}{l}\text { Intron6position- } \\
\text { 155delC }\end{array}$ & & Frame shift & & $\begin{array}{l}\text { Abnormal } \\
\text { splicing, } \\
\text { missing } \\
\text { terminus }\end{array}$ & \\
\hline c. $2071 \mathrm{~T}>\mathrm{C}$ & $\begin{array}{l}\text { Compound } \\
\text { heterozygous }\end{array}$ & Cys691Arg & 1 & $\begin{array}{l}\text { Increased } \\
\text { proteosomal } \\
\text { degradation }\end{array}$ & \\
\hline Intronic SNP & $\begin{array}{l}\text { Compound } \\
\text { heterozygous }\end{array}$ & Frame shift & 1 & $\begin{array}{l}\text { Transcripts } \\
\text { lacking exons } \\
2-4 \text { or } 3-4\end{array}$ & \\
\hline $\begin{array}{l}\text { c.1529_1541dupC } \\
\text { CAGCGCCCCAC } \\
\text { T }\end{array}$ & $\begin{array}{l}\text { Compound } \\
\text { heterozygous }\end{array}$ & $\begin{array}{l}\text { Met515 } \\
\text { frame shift } \\
\text { 563stop }\end{array}$ & 1 & $\begin{array}{l}\text { Missing } \\
\text { terminus }\end{array}$ & \\
\hline c. $235 \mathrm{C}>\mathrm{T}$ & & Gln79stop & & $\begin{array}{l}\text { Smaller } \\
\text { isoforms }\end{array}$ & \\
\hline
\end{tabular}

Received: December 1, 2013 